Review

\title{
Fire-Induced Changes in Soil and Implications on Soil Sorption Capacity and Remediation Methods
}

\author{
Veronica M. Ngole-Jeme \\ Department of Environmental Science, School of Ecological and Human Sustainability, \\ College of Agriculture and Environmental Sciences, UNISA, Florida 1710, Roodepoort, Gauteng, South Africa; \\ ngolevm@unisa.ac.za
}

Received: 27 April 2019; Accepted: 12 June 2019; Published: 21 August 2019

\begin{abstract}
Vegetation changes caused by fire events are visible instantly but changes in soils are less apparent, and could be short-term, long-term or permanent in nature. Research has shown that soils undergo changes in their mineralogical, geochemical, physico-chemical and biological properties after a fire event that may vary depending on the intensity and duration of the fire, and the properties of the soil. Some of these properties make significant contributions towards soil's ability to sorb contaminants. Changes in these properties could affect soil sorption complex and the effectiveness of remediation methods used to clean these soils when contaminated. This review synthesizes available information on fire-induced changes in soil properties affecting soil sorption and the factors which dictate these changes. The implications of changes in these properties on the soil's natural attenuation capacity and choice of remediation method to clean up fire-affected contaminated soils are also discussed.
\end{abstract}

Keywords: soil mineralogy; fire intensity; contaminated soil; biochar; soil thermal conductivity; organic matter

\section{Introduction}

Fire events are becoming more frequent in occurrence, and larger in terms of areal coverage [1]. Analyses of charcoal records in sediments and isotopic records in ice cores have indicated lower biomass burning in present times than any time in the previous 2000 years [2,3], but Huang et al. [1] and North et al. [4] reported an increase in the occurrence of wildfires. Data from Europe, Australia, and New Zealand also show a decline in the occurrence of fire events but similar data sets from South East Asia, the Middle East and North America show an increase [5]. Results from studies carried out around the globe indicate that spatially, fire incidents occur in every continent except Antarctica whereas temporal occurrence is related to climatic changes [6]. According to Huang et al. [1], lightning, climate change and precipitation will account for 3.6\%, 19\%, and 36.7\% increase in the occurrence of wildfires respectively by the year 2050. Lightning, volcanic eruptions, and sparks from rock falls are natural occurrences which have been cited as being responsible for wildfires. Increased occurrences of fire events in recent years have been associated mainly with anthropogenic activities aimed at promoting habitat diversity, stopping bush encroachment, controlling and/or eliminating pathogens (thermosanitation), and preparing land for planting [7-19]. Fires have also been used for training firefighting personnel [20]. Improper waste disposal practices, slash and burn agriculture, and clearing of rangelands are some human activities which have caused accidental fires in recent times. Ecological factors including vegetation cover have also been identified to play a role in the occurrence of wildfires [21,22]. Whereas human influences ignite fires, ecological factors are said to determine whether a fire will spread once it has been ignited. The cause of fire incidents and their occurrence and spread are therefore influenced by several factors most of which are related to human activities. 
Whether natural or human induced, fires have been classified as ground fires (which burn near the ground surface), surface fires (which burn shrubs, larger plants and lower branches of trees), and crown fires which mainly burn trees. Fires have also been described as flaming fires which burn at higher temperatures and spread faster or smoldering fires which burn more slowly, have lower temperatures, and are usually flameless [23]. Smoldering fires destroy large amounts of biomass and cause severe damage to the soil ecosystems $[24,25]$. Ground fires typically burn by smoldering and can last for days to months with relatively low temperatures $\left(500^{\circ} \mathrm{C}\right.$ to $\left.700{ }^{\circ} \mathrm{C}\right)$ compared to flaming fires $\left(1500{ }^{\circ} \mathrm{C}\right.$ to $\left.1800{ }^{\circ} \mathrm{C}\right)$ [25]. Fires likely to affect soils are ground fires and crawling or surface fires because of their proximity to the soil surface.

Irrespective of whether they are natural or manmade, fire events affect the ecosystems in which they occur in several ways. According to Certini [26], soil properties could experience short-term, long-term and permanent fire-induced changes which may trigger ecosystem wide impacts with consequences on ecosystem resilience and stability. In contaminated soils where natural attenuation processes are hindered by the presence of high concentrations of contaminants, fire-induced changes in soil properties could have serious consequences. These changes could influence soil sorption and attenuation capacities and dictate the choice of remediation method to use on fire-affected contaminated sites. This paper reviews soil- and fire-related factors that dictate changes in selected soil properties during fire events and the extent to which these properties are affected. It also discusses how these changes may affect soil sorption capacity and the choice of remediation methods used on contaminated fire-affected soils.

\section{Factors Which Determine the Effect of Fire Events on Soil Properties}

The temperature ranges within which various soil properties undergo changes have been reported by Santín and Doerr [10]. According to these authors, changes in biological, chemical and physical properties caused by fire events are experienced at soil temperature ranges between $50-150{ }^{\circ} \mathrm{C}, 200^{\circ} \mathrm{C}$ and above, and $50-700{ }^{\circ} \mathrm{C}$, respectively [10]. These changes occur as a result of several factors which can be broadly grouped as vegetation-related, fire-related, and soil-related. The role of these factors in the changes in soil properties during fire events are reviewed in the following sections.

\subsection{Type of Vegetation}

Vegetation is the main fuel responsible for wildfire events [21,22]. Fire intensity generally increases with increase in vegetation cover because of availability of fuel. It is not only the quantity, but the type of vegetation that dictates fire intensity and, consequently, the changes in soil properties. Vegetation flammability varies throughout the year due to changes in its chemical composition, moisture content, leaf biomass and the proportion of dead to live plants [27]. The intensity and duration of fire could therefore also vary throughout the year according to vegetation characteristics. Badía et al. [28] showed that higher soil temperatures are encountered during fire events fueled by woody species compared to those fueled by grasses and shrubs. Furthermore, fires on soils with woody species are hotter and also burn for longer periods, a characteristic which has been attributed to the high content of lignin in woody species. Lignin is a high-molecular-weight insoluble polymer composed of methoxylated derivatives of benzene and are thus aromatic in nature. This complex aromatic structure locks up a higher amount of energy in its carbon chain compared to aliphatic structures. Lignin therefore provides fuel over a longer period of time, hence the longer duration of fire on soils covered with woody species. On croplands with plant residue that comprise of cellulose- and glucose-rich polysaccharides (aliphatic compounds), wildfire events would cause soils to be heated for shorter periods because these compounds have a less complex structure with lower amounts of energy when compared with lignin. Soils under woody vegetation are therefore most likely heated to higher temperatures and for longer periods during fire events compared to soils under non-woody vegetation. Stoof et al. [29] have reported that soils in areas that are sparsely vegetated experience higher temperatures during fire events than more densely vegetated areas. This, however, contradicts the findings of Badía et al. [28], who established a 
positive correlation between high vegetation density and high soil temperatures during fire events. Other factors besides fuel content could therefore be responsible for soil temperatures attained during fire events. The presence of stumps, logs, roots and peat in soils also provide fuel for combustion and could result in soil temperatures of up to $1500{ }^{\circ} \mathrm{C}$ during fire events [25]. Vegetation not only influences the temperature of surface soils, but through the network of roots below the soil surface, it also affects the depth to which subsurface soils are heated.

\subsection{Fire Intensity and Duration}

Fire intensity refers to the energy or heat released during various phases of a fire, and is determined by the type of fuel available and how fast this fuel burns [30]. Fire temperature is commonly used to describe fire intensity with low, medium, and high fire intensity having temperatures of $250{ }^{\circ} \mathrm{C}$ maximum, $400{ }^{\circ} \mathrm{C}$ maximum and above $675^{\circ} \mathrm{C}$, respectively [31,32]. Waldrop and Brose [33] have also classified fire intensity according to the height of the flame produced by the fire relative to forest stands. This classification may, however, not be applicable where there are smoldering fires which may be flameless yet could have relatively high temperatures (high intensity based on the description of Reynard-Callanan et al. [31] and Janzen and Tobin-Janzen [32]), or where there are mainly grasses or shrubs present. Though several studies have indicated that only superficial and slight soil heating occurs during fire events, more recent studies have reported surface soil temperatures of $125^{\circ} \mathrm{C}$ and $200{ }^{\circ} \mathrm{C}$ [34], $310^{\circ} \mathrm{C}$ [35], $500{ }^{\circ} \mathrm{C}$ [31], ranges of $<225^{\circ} \mathrm{C}$ for grasslands to $700{ }^{\circ} \mathrm{C}$ in shrub lands [36], $704^{\circ} \mathrm{C}$ [37], $1000{ }^{\circ} \mathrm{C}$ [38] and $1000-1500{ }^{\circ} \mathrm{C}$ [25] during various smoldering and flaming fire events on soils with different vegetation types. Subsurface soils also experience increases in temperature which are not necessarily proportional to the intensity of the fire. In a study of sugarcane burning in Cuba, Velasco [39] reported flame temperatures of between $600{ }^{\circ} \mathrm{C}$ and $750{ }^{\circ} \mathrm{C}$, but soil temperature at a depth of $2 \mathrm{~cm}$ never exceeded $34^{\circ} \mathrm{C}$. Cesar [40] reported a soil temperature of $280^{\circ} \mathrm{C}$ at depths of $1 \mathrm{~cm}$, and $200{ }^{\circ} \mathrm{C}$ at depths of $2 \mathrm{~cm}$ for a fire which lasted $10 \mathrm{~h}$. In grasslands, subsurface soil temperatures rarely exceed 50 to $80^{\circ} \mathrm{C}$ during wildfire events according to Cawson et al. [41]. Generally, temperatures of $300{ }^{\circ} \mathrm{C}$ to $900{ }^{\circ} \mathrm{C}$ have been reported at the litter layer, $100{ }^{\circ} \mathrm{C}$ to $625^{\circ} \mathrm{C}$ at the litter-duff interface, $80^{\circ} \mathrm{C}$ to $210^{\circ} \mathrm{C}$ at the mineral soil surface, and $25^{\circ} \mathrm{C}$ to $200{ }^{\circ} \mathrm{C}$ at soil depths of $2.5 \mathrm{~cm}$ [41]. The variation of soil temperature with depth during fire events also varies. A steep temperature gradient of $590^{\circ} \mathrm{C}$ at the surface to $131{ }^{\circ} \mathrm{C}$ at a depth of $3 \mathrm{~cm}$ in soil has been reported by Badía et al. [28] during fire events, indicating a decrease in soil temperature with depth as the fire burns. This gradient, however, is determined by the moisture characteristics of the soil. Surface and subsurface soil temperatures attained during fire events are therefore highly variable, and may not be easily predicted. The higher the intensity of a fire, the more likely it is that the soil will experience changes in its properties.

Bova and Dickenson [42] have shown that fire duration plays a more significant role in the changes observed in vegetation during fire events than fire intensity, which could also be the case with soils. Fire of longer duration would cause more, and lasting, changes in soil properties compared to fires that occur for shorter periods. The duration of a fire is influenced mainly by fuel type and soil characteristics. Fire on coarse-textured soils rich in woody species is likely to burn for a longer period than fire on fine-textured soil with grassland species [43], possibly because of the availability of fuel over a longer period of time. According to Santín and Doerr [10], soils with organic matter richer in aromatic than aliphatic moieties are also likely to burn for longer periods. The effect of fire intensity on soil properties could be moderated by fire duration. Changes in $\mathrm{pH}, \mathrm{CEC}$ and organic matter content of soils exposed to temperatures of $150^{\circ} \mathrm{C}$ for $6 \mathrm{~h}$ were similar to those observed in another sample of the same soil exposed to temperatures of $300{ }^{\circ} \mathrm{C}$ for $4 \mathrm{~h}$, and $700{ }^{\circ} \mathrm{C}$ for $2 \mathrm{~h}$ in laboratory studies [44]. The type of fire is also significant. Flaming fires are noted to burn for shorter periods compared to smoldering fires [25]. These observations indicate that fire duration and intensity together influence the degree to which fire affects soil properties, with fire of lower temperature and longer duration having a similar effect to fire of higher temperature and shorter duration. 


\subsection{Soil Properties}

Soil properties, including moisture content, texture, density, organic matter content, and mineralogy, influence the extent to which fire incidents could affect soil. This influence is related to the role they play in soil thermal conductivity. Soil thermal conductivity refers to the quantity of heat that flows through a unit area in a unit time under a unit temperature gradient [45] and is affected by the degree of soil saturation, dry density, mineral composition, temperature, texture, and time $[46,47]$. Coarse-textured, wet, and organic matter-rich soils have higher conductivity than vice versa and provide a conductive platform for wildfires [26,48-51]. Wildfires on moist soils would result in higher soil temperatures compared to dry soils [28]. According to Badía et al. [28], the temperature gradient of dry soil is much steeper with depth than what is obtained in wet soil. Sand particles also support high heat conductivity and would likely increase the temperature of soils in the event of a fire more than finer soil particles due to the high thermal conductivity of quartz $(7.70 \mathrm{~W} / \mathrm{m} / \mathrm{k})$, which dominates coarse (sand) particles [52]. Soil packing density (defined as a composite index of bulk density and clay content) also influences the conduction of heat within the soil environment and therefore the depth and extent to which a soil is heated. The higher the packing density of soil, the better its thermal conductivity and the higher the temperature of soil will be raised in the event of a wildfire $[53,54]$. Soil minerals vary in their thermal conductivity and temperature threshold depending on their structural properties. Studies by Jõeleht et al. [55] reported thermal conductivities for dolomite, calcite, smectites, muscovite/illite, chlorite and the K-feldspars to be $4.8-5.5 \mathrm{~W} / \mathrm{m} / \mathrm{k}, 3.3-3.6 \mathrm{~W} / \mathrm{m} / \mathrm{k}$, 3.3-6.2 W/m/k, $1.9 \mathrm{~W} / \mathrm{m} / \mathrm{k}, 1.9-2.5 \mathrm{~W} / \mathrm{m} / \mathrm{k}$, and 2.4-2.6 W/m/k respectively. These differences could play a significant role in the extent of changes in soil properties during fire events. Soils dominated by secondary minerals are less likely to experience changes compared to those with primary mineral because of the differences in their thermal conductivities. Densely packed, moist, and coarse-textured soils are also likely to be heated to a greater extent and depth than porous soils and would therefore experience more changes in their properties after a fire event.

\section{Fire-Induced Changes in Soil Properties and the Implications on Soil Sorption Capacity}

Fire affects soil physical, chemical, mineralogical and biological properties to different extents depending on the temperature to which the soil is raised during fire incidents. Soil physical properties commonly affected by fire include moisture content, color, structure, aggregate stability, water repellency, and texture [26,48-50]. Details of the effects of fire on these soil physical properties have been reported by several authors $[26,48-50,56-69]$. Soil chemical properties are affected at temperatures as low as $50{ }^{\circ} \mathrm{C}$, where soil moisture characteristics start undergoing changes up to temperatures above $700{ }^{\circ} \mathrm{C}$, where oxyhydroxides and carbonates are converted to oxides and the $\mathrm{pH}$ of the soil increases as a result of the accumulation of ash [10]. Soil chemical properties said to be affected by fires include soil $\mathrm{pH}[16,26,49,70-75]$, nutrient content [26,76-78], organic matter content and cation exchange capacity [10,79-85], and major and trace element oxide concentrations [16,26,44,49,76-78,86-96]. Fire-induced soil mineralogical changes occur both at low and high fire intensities, and are concentrated where the fire is intense and of a longer duration. These changes have been reported by Reynard-Callanan [31], Ngole-Jeme [44], Tan et al. [97], Zihms et al. [50], Yusiharni and Robert [98], Ketterings et al. [67], Cornell and Schwertmann [99], Reynard-Callanan et al. [31], Araya et al. [51], Frost et al. [100], Arocena and Opio [16], Richardson [101], and Ulery and Graham [66]. Fire also affects soil biological properties $[10,26,68,102-109]$. Changes in these properties affect several soil chemical processes including sorption processes in different ways.

The removal of a compound from solution to solid phase is described as sorption [110]. Sorption of contaminants by soil reduces their mobility in the soil environment and consequently the risks that they pose to various environmental receptors. Soil sorption processes play a significant role in the maintenance of proper soil structure, supply of plant nutrients, their migration and bioavailability, and the mobility, dissolution and neutralization of contaminants in the soil environment [111]. Soil is a complex heterogeneous material with peculiar properties which make up its sorption complex. 
The total sorption capacity of a soil is a function of the sum of the individual sorption capacities of various soil components (clay content, organic matter content, and sesquioxizes) and properties including soil texture, cation exchange capacity (CEC), mineralogy, and $\mathrm{pH}$ [112]. Soil sorption behavior is therefore described as complex, and anything affecting any one of these soil components or properties is likely to affect soil sorption complex and its sorption capacity. Changes in soil temperature caused by fire affects these soil properties and consequently soil sorption capacity in different ways. This section of the review looks at fire-induced changes in soil properties that make up its sorption complex and the implications of these changes on its sorption capacity.

\subsection{Fire-Induced Changes in Soil Textural Properties and Implications on Soil Sorption}

Though soil particles have high threshold temperatures $\left(460-980{ }^{\circ} \mathrm{C}\right.$ for clay and $1414{ }^{\circ} \mathrm{C}$ for sand), several authors have reported that wildfires affect soil particles and consequently soil texture $[26,48-50,68]$. Clay particles begins to experience changes in structure at temperatures of $400{ }^{\circ} \mathrm{C}$ due to hydroxylation and collapse of the clay lattice structure, and can be completely destroyed at $700-800^{\circ} \mathrm{C}$. This occurs mainly because of the dominance of secondary minerals in the clay fraction of soils. Sand and silt particles on the other hand are more thermally stable because they comprise mainly of quartz, which has a melting point of $2577^{\circ} \mathrm{C}$ as well as a high thermal conductivity, and can only be affected under extreme soil temperatures not normally attained during wildfire events. Neary et al. [68] showed that clayey soils are more susceptible to fire-induced changes compared to sandy and silty soils, and he attributed this to differences in their mineral composition. According to Ulery and Graham [66], Ketterings et al. [67], and Obale-Ebanga et al. [113], soil temperatures above $600{ }^{\circ} \mathrm{C}$ result in a sharp increase in sand content and a decrease in silt and especially clay content in soils. Begum et al. [69] have associated the increase in particle size of soils after fire events with the conversion of $\mathrm{CaO}$ to $\mathrm{Ca}$ which results in agglomeration, whereas Raison et al. [78], Bodí et al. [86] and Stoof et al. [114] have implicated swelling of ash particles. Destruction of kaolin during fires results in the production of oxides and hydroxides of $\mathrm{Al}$ and $\mathrm{Si}$ which are cementing agents capable of aggregating clay particles into sand-sized ones [115] that could also result in the observed increase in coarseness of soils after fire events.

Accumulation of sand-sized particles in soils after a fire event is likely to reduce soil sorption capacity. Falciglia et al. [116] have shown that soil texture influences contaminant sorption in soils by up to $37.1 \%$ with finer soil particles playing a major role. This influence has been attributed to the cation exchange capacity (CEC) of the various soil particles which, according to Schulten and Leinweber [117] increases from $10 \mathrm{mmol} / \mathrm{kg}$ in sandy soil to $813 \mathrm{mmol} / \mathrm{kg}$ in fine clay (Table 1).

Table 1. Cation exchange capacity of soil particles.

\begin{tabular}{|c|c|}
\hline Soil Particle & Cation Exchange Capacity Range $\mathrm{cmol}(+) / \mathrm{kg}$ \\
\hline Fine clay & $57.4-81.3$ \\
\hline Coarse clay & $33.6-74.9$ \\
\hline Whole clay & $20.9-110.0$ \\
\hline Fine silt & $6.8-41.4$ \\
\hline Medium silt & $63-34.5$ \\
\hline Coarse silt & $1.2-12.8$ \\
\hline Sand & $1.0-15.6$ \\
\hline
\end{tabular}

The role of soil texture in the sorption of inorganic and organic contaminants is well documented. Studies have shown that absorption of Diuron (a urea herbicide) on soil particles for example is three times higher in the $<50 \mu \mathrm{m}$ fraction of soil compared to the 50-2000 $\mu \mathrm{m}$ fraction [118]. The concentration of polycyclic aromatic hydrocarbons $(\mathrm{PAH})$ in the $<63 \mu \mathrm{m}$ fraction of river sediments has also been shown to be higher than in the 1000-2000 $\mu \mathrm{m}$ fraction, indicating a higher sorption of PAH by fine particles [119]. Studies by Iturri et al. [120] have indicated that the electrochemical properties of soils 
are not only contributed by the clay fraction, but silt particles, especially those with diameters between 2 and $20 \mu \mathrm{m}$, also play a major role as well. Silt fraction of soils contribute up to $17.5 \%$ of CEC to the total soil CEC [120]. Increased sand-sized particles in soils after fire events reduces the total soil surface area and surface charge density with a consequent reduction of their CEC. This would affect the overall sorption capacity of the soil and its attenuation of both organic and inorganic contaminants. Increase in coarseness of soils post fire events would therefore result in a decrease in the fraction of the soil sorption capacity contributed by the clay fraction, and consequently on the soil's overall ability to sorb cationic and organic compounds.

\subsection{Fire-Induced Changes in Soil Mineralogical Properties and the Implications on Soil Sorption Capacity}

Changes in soil mineralogy caused by fire are correlated with the moisture condition of the soil according to Reynard-Callanan [31], and vary with type of soil. Laboratory experiments by Ngole-Jeme [44] revealed significant changes in the mineralogy of uncontaminated soils at about $300{ }^{\circ} \mathrm{C}$ whereas in mine tailings contaminated soil, similar changes were only observed at $500{ }^{\circ} \mathrm{C}$ (Table 2). Changes in the mineralogy of both contaminated and uncontaminated soils occur after $4 \mathrm{~h}$ of heating at temperatures of $300{ }^{\circ} \mathrm{C}$ and after $2 \mathrm{~h}$ of heating at $500{ }^{\circ} \mathrm{C}$ [44]. These changes could be attributed to the conversion of secondary mineral to primary minerals as a result of dihydroxylation. Although Tan et al. [97] have shown that the mineralogical assemblage of soil is not affected by fires below $500{ }^{\circ} \mathrm{C}$, Zihms et al. [50] and Yusiharni and Robert [98] have also shown that soil mineralogical composition could be affected by fire events with temperatures as modest as $200-600^{\circ} \mathrm{C}$.

Table 2. Effect of heat duration and intensity on mineralogical composition of soils.

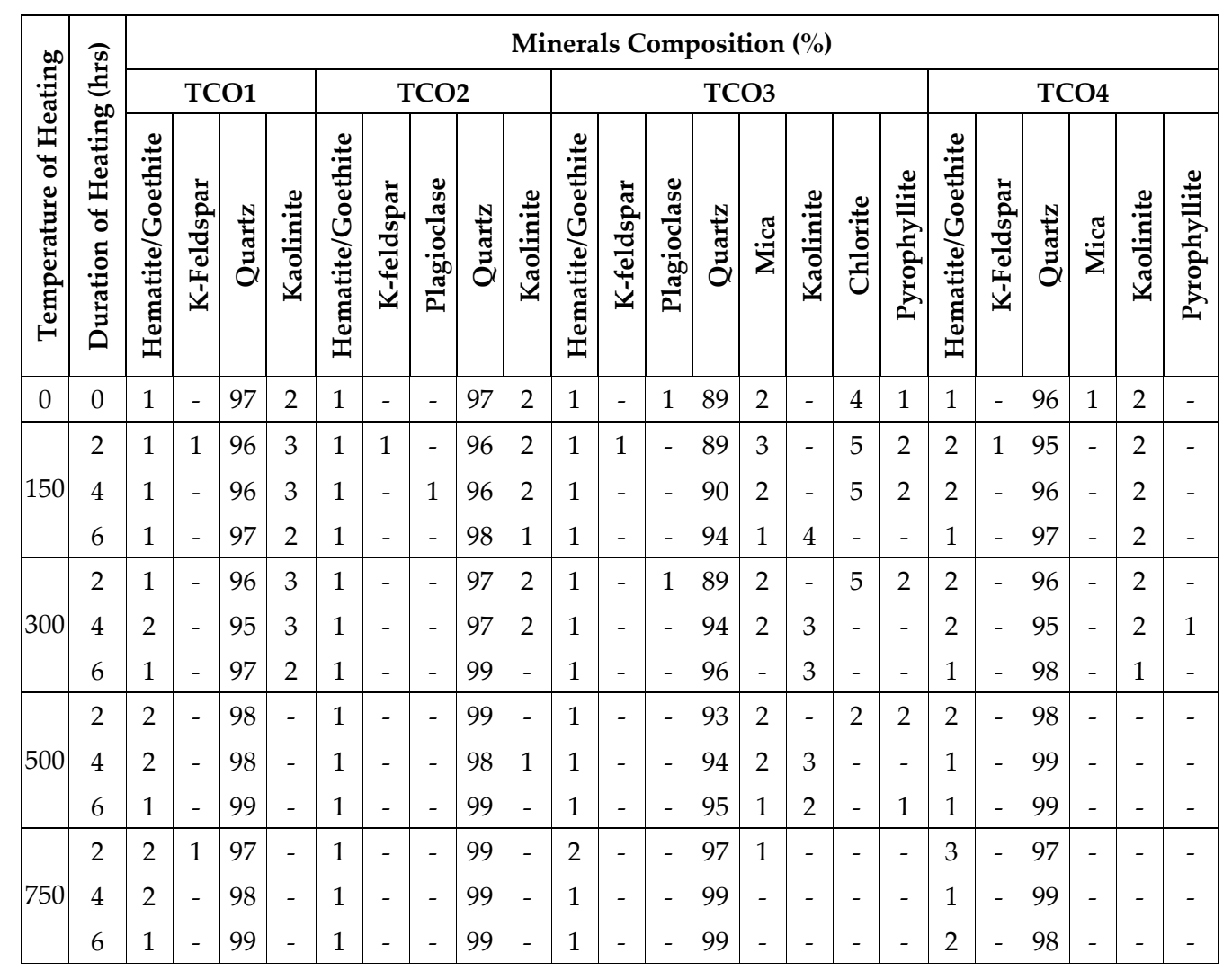

Results from research on the effect of soil temperature changes on soil mineralogy show that both primary and secondary soil minerals are affected by fire events. Quartz, for example, is unaffected when exposed to temperatures of $600{ }^{\circ} \mathrm{C}$ or greater, but diminished intensities of quartz peaks have been reported at this temperature as well. Ketterings et al. [67] reported unchanged quartz peak 
intensities at $300^{\circ} \mathrm{C}$, but lower peaks after exposure of subsoil to temperatures of $600{ }^{\circ} \mathrm{C}$. The content of $\mathrm{K}$-feldspars in soil has also been shown to decrease with increasing soil temperatures, whereas quartz content increases as indicated in Table 2 [44]. No changes in hematite content of soils were reported at temperatures of $750{ }^{\circ} \mathrm{C}$ by Ngole-Jeme [44], and calcareous soils have also been shown to resist changes up to temperatures of about $1000^{\circ} \mathrm{C}$. Cornell and Schwertmann [99], however, observed that gibbsite alters to amorphous phase at temperatures as low as $200^{\circ} \mathrm{C}$, whereas goethite is transformed to hematite at temperatures of approximately $300^{\circ} \mathrm{C}$. The contribution of soil primary minerals to its sorption capacity is, however, lower than that of secondary minerals (Table 3), so fire-induced changes in primary minerals may have a negligible effect on the soil's overall sorption capacity. The situation with secondary minerals is, however, different.

Table 3. Cation exchange capacity of various soil minerals.

\begin{tabular}{cc}
\hline Soil Mineral & Cation Exchange Capacity (Meq/100 g) \\
\hline Montmorillonite (smectites) & $80-50$ \\
Vermicullite & $100-150$ \\
Illite & $20-40$ \\
Kaolinite & $3-15$ \\
Allophane & $5-30$ \\
Gibbsite & $0-4$ \\
Hematite/goethite & $4-100$ \\
Halloysite & $5-50$ \\
glauconite & $5-40$ \\
Sesquioxides & $0-1$ \\
\hline
\end{tabular}

The effects of fire on secondary minerals occur at much lower temperatures compared to the primary minerals possibly because of their lower thermal conductivity, and vary with type of clay mineral. Dehydroxylation of most minerals occurs when soil temperatures are raised to about $500{ }^{\circ} \mathrm{C}$, but Reynard-Callanan et al. [31] have shown that though phyllosilicates like micas and vermiculite are affected by fire events of high intensity, they are not completely decomposed. Araya et al. [51] and Frost et al. [100] reported the disappearance of kaolinite at $500{ }^{\circ} \mathrm{C}$ and attributed this to loss of hydroxyl ions from the lattice structure of kaolinite and formation of metakaolinite thereof. Ketterings et al. [67] has reported the loss of kaolinite and formation of a glassy phase at soil temperatures above $600{ }^{\circ} \mathrm{C}$. These observations, however, contradict those of Arocena and Opio [16] who showed shifts in kaolinite peaks ( $d$-spacings), but no complete destruction at similar temperatures. Richardson [101] also documented decomposition of kaolinite at temperatures between $500-700{ }^{\circ} \mathrm{C}$ after losing lattice water. Fire-induced changes in smectitic and vermicullite clay minerals have been reported by Reynard-Callanan et al. [31] and Ulery and Graham [66], and they too associated these to dihydroxylation. Ulery and Graham [66] reported transformation of chlorite and vermiculite to illite and complete decomposition of kaolinite in the top $8 \mathrm{~cm}$ of soil as a result of fire events whereas Arocena and Opio [16] showed evidence of reduction in 2:1 clay mineral in soils after fire events.

Silicate clays and metal-(oxyhydr)oxides are among the major sorbents in the soil environment. The chemical substitution of structural components of layer silicate clays which comprise of stacks of aluminum-oxygen and silicon-oxygen sheets by ions of lower valance gives them a predominant negative charge. These soil components therefore make significant contributions towards soil sorption capacity. These contributions, however, vary with mineral type. Studies by Martín-García et al. [121] indicate that 2:1 clay mineral have a higher CEC than 1:1 type clay mineral and even within the 2:1 type, smectites contribute more to soil CEC than Illite (Table 3). This difference is associated with the presence of an internal and external surface area in 2:1 clays, which increase the total surface area of the clays as well as its surface charge density. Shifts of mineral assemblage from secondary to primary minerals, as well as dihydroxylation of clay minerals observed in fire-affected soils would 
result in a decrease in its sorption capacity and consequently its ability to immobilize both organic and inorganic compounds.

Oxides of iron (Fe) and aluminum, which usually occur as coatings on clay particles, also play a significant role in soil sorption capacity especially under oxidizing conditions [122]. These metal-(oxyhydr)oxides have a variable charge because their surfaces become hydroxylated when exposed to water. They could be anionic $\left(-\mathrm{MO}^{-}\right)$, neutral $(-\mathrm{MOH})$, or cationic $\left(-\mathrm{MOH}^{2+}\right)$ depending on the degree of protonation they undergo, which in itself is determined by the prevailing $\mathrm{pH}$ conditions. They have a net positive surface charge at low $\mathrm{pH}$, a net negative surface charge at high $\mathrm{pH}$, and are neutral at circumneutral $\mathrm{pH}$ conditions [123]. Metal oxides have very high temperature thresholds, which may not be encountered by the soil during fire events. Figure 1 presents changes in concentrations of $\mathrm{SiO}_{2}, \mathrm{Al}_{2} \mathrm{O}_{3}$, and $\mathrm{Fe}_{2} \mathrm{O}_{3}$ in soil heated at different temperatures for different lengths of time. No significant changes were observed when soils were heated below $500{ }^{\circ} \mathrm{C}$, confirming that these oxides are unlikely to be affected by fire events of low intensity. In studies on both contaminated and uncontaminated soils by Ngole-Jeme [44], few changes were observed in the content of major and trace element concentrations between temperatures of $0-700{ }^{\circ} \mathrm{C}$, except for $\mathrm{MgO}, \mathrm{CaO}, \mathrm{MnO}$, and $\mathrm{K}_{2} \mathrm{O}$ concentrations, which increased with increase in temperature and duration of heating. The observed increase in these oxides could have come about as a result of their release during transformation of organic matter as the soil temperature increases. Except for Mn, these oxides, however, play little role in soil sorption and so fires would have little influence on the fraction of soil sorption capacity contributed by major and trace element oxides, but heating soils above temperatures of $600{ }^{\circ} \mathrm{C}$ would likely result in an increase in the content of $\mathrm{SiO}_{2}, \mathrm{Al}_{2} \mathrm{O}_{3}$, and $\mathrm{Fe}_{2} \mathrm{O}_{3}$ in the soil (Figure 1) and a consequent increase in the contribution they make to the soil sorption complex.

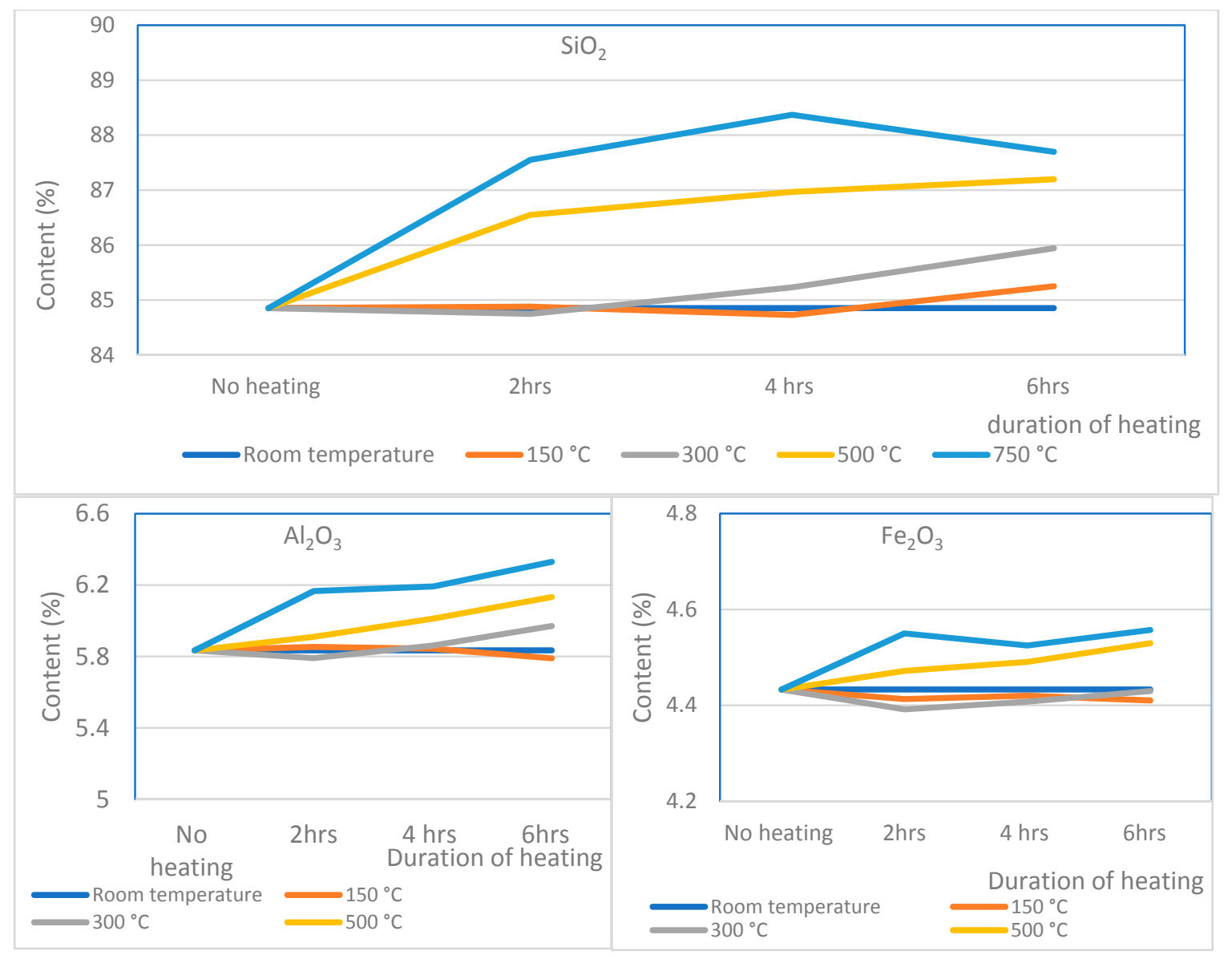

Figure 1. Changes in soil $\mathrm{SiO}_{2}, \mathrm{Al}_{2} \mathrm{O}_{3}$, and $\mathrm{Fe}_{2} \mathrm{O}_{3}$ content with increase in temperature and duration of heating. 


\subsection{Fire-Induced Changes in Soil Organic Matter Content and the Implications on Soil Sorption Capacity}

According to Lair et al. [112] and Hyun et al. [123], organic matter is the single most important factor affecting the sorption of heavy metals, pesticides and other organic compounds in soils. Soil organic matter has several reactive sites ranging from potentially anionic hydroxyls $(\mathrm{R}-\mathrm{OH})$ and carboxylic groups ( $\mathrm{R}-\mathrm{COOH})$, to cationic sulfhydryl ( $\mathrm{R}-\mathrm{SH})$ and amino groups $\left(\mathrm{R}^{-} \mathrm{NH}_{2}\right)$, as well as aromatic (-Ar-) and aliphatic ([- $\left.\left.\mathrm{CH}_{2}-\right] \mathrm{n}\right)$ moieties that are the main un-charged, non-polar regions of the soil solid phase. The amount of these moieties in any given soil varies, and so does their surface area and chemical composition, which significantly influence the sorption characteristics of any given soil. Organic matter contribution to soil sorption is more pronounced in sandy soils than in clayey soils, where clay minerals are the main contributors [117]. Changes in organic matter structure and content in soils could reduce or increase soil sorption capacity. During fire events, organic matter undergoes a series of changes which include free vaporization of moisture at $100{ }^{\circ} \mathrm{C}$, degradation and decomposition of lignin and hemicellulose between $130^{\circ} \mathrm{C}$ and $200{ }^{\circ} \mathrm{C}$, chemical dehydration of cellulose at $280{ }^{\circ} \mathrm{C}$, smoldering between $500-600{ }^{\circ} \mathrm{C}$, and flaming/igniting between $800-1500{ }^{\circ} \mathrm{C}[79,80]$. Fires with temperatures of between 250 and $460^{\circ} \mathrm{C}$ could cause volatilization, charring or complete oxidation of soil organic matter. At these temperatures, González-Pérez et al. [81] and Santín and Doerr [10] indicated that aromatic compounds accumulate at the expense of aliphatic ones. Though soil organic matter content is drastically reduced by wildfires, organic components including free lipids, and humic acids have been shown to increase [82], with new aromatic compounds being formed from the alteration of carbohydrates [83]. Studies by Almendros et al. [84] indicate that chain length in lipids is decreased, whereas González-Pérez et al. [81] showed that changes in solubility of humic substances occur. González-Vila et al. [85] also noted that aromaticity of organic material increases as soil temperatures increase. González-Pérez et al. [81] have described the changes caused by fire on humic substances as:

- Total removal of external oxygen-containing functional groups, leading to the formation of substances with low solubility,

- Decreased aliphatic chain length of humic acids and other hydrocarbons,

- Increased degree of aromaticity in organic matter,

- Structural changes in humic acids, including polymerization,

- Formation of nitrogen-containing heterocycles

- Formation of black carbon.

Burning of organic matter in soils not only produces ash, but pyrogenic carbon (biochar or charcoal) is also produced when plant biomass is exposed to fire at temperatures below $900{ }^{\circ} \mathrm{C}$ in oxygen-limited conditions. This could occur during ground or smoldering fires which take place below the surface of soils that have woody plant roots and high organic matter in the surface layer. The high sorption capacity of charcoal has been acknowledged in studies by Araya et al. [51], Wang et al. [124], Zhelezova et al. [125], and Pingree and DeLuca [126]. Inyang et al. [127], for example, reported Pb, $\mathrm{Ni}, \mathrm{Cd}$ and $\mathrm{Cr}$ absorption capacities by biochar to be $2.4-147,19.2-33.4,0.3-39.1$, and $3.0-123 \mathrm{mg} / \mathrm{g}$, respectively, highlighting the contribution of this material to soil sorption when present. According to Pingree et al. [128], as the temperature at which charcoal in soil is formed increases, the absorption capacity of the produced charcoal increases. Fires of high intensity, especially under poorly aerated conditions, could therefore increase soil sorption capacity due to the formation of biochar. This condition is, however, not permanent, because of biochar oxidation over time [129], though Pingree et al. [128], Hammes and Schmidt [130], and Liang et al. [131] have indicated that oxidation of biochar results in the evolution of negative charges in soil which increases soil CEC. Where burning occurs under aerobic conditions, organic matter is completely oxidized to ash. Transformation of alcohols, humic and fulvic acids contained in organic matter by fire events under these conditions would result in a decrease in the density of negative charges on the soil with a consequent decrease in CEC and soil sorption capacity. In burnt soils, the organic matter content is drastically reduced, which may reduce 
soil CEC. A decrease in soil CEC with increase in soil temperature was been reported in laboratory studies [44] (Figure 2). These effects have been associated with the ash content from organic matter in burnt soils [132].

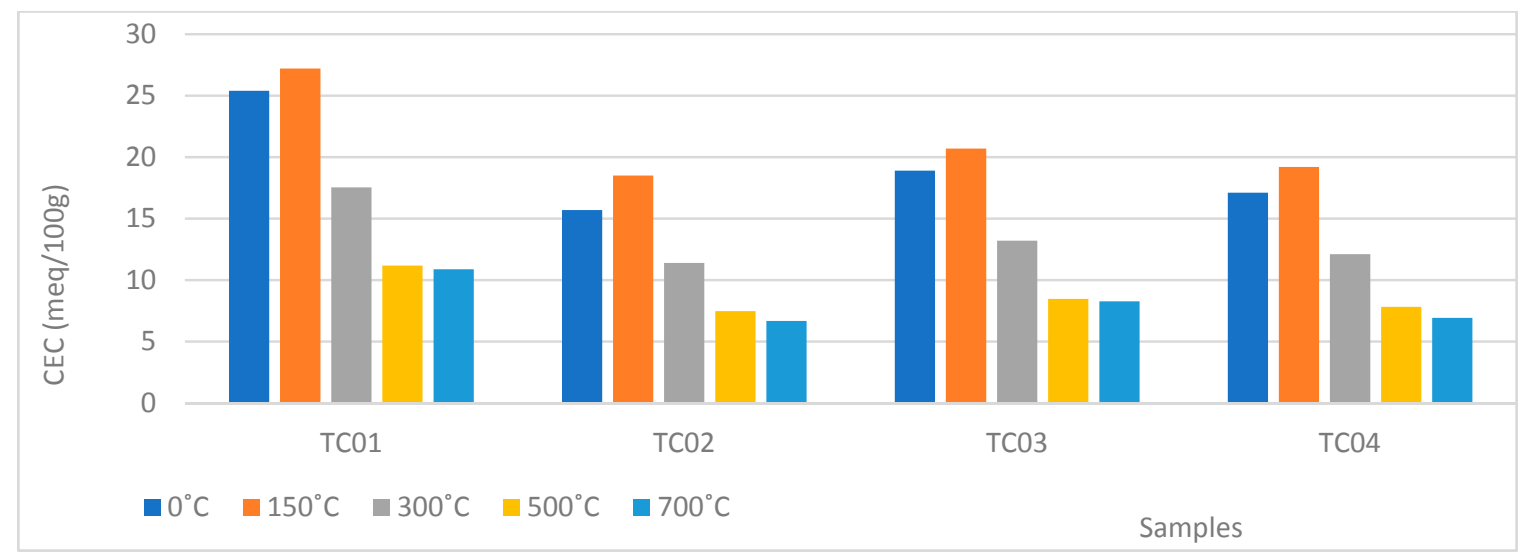

Figure 2. Decrease in soil CEC with increase in temperature.

\subsection{Fire-Induced Changes in Soil pH and Implications on Soil Sorption}

Reports of the effects of fire on soil $\mathrm{pH}$ are contradictory. Whereas fire-induced increase in soil $\mathrm{pH}$ has been reported by Arocena and Opio [16], Certini [26], Badía and Martí [49], and other researchers [70-73] have shown that heating between 250 and $500{ }^{\circ} \mathrm{C}$ lowers soil pH. Most of the studies which reported a decrease in $\mathrm{pH}$ were, however, carried out in the lab, which does not take into consideration the effect of the ashes produced from burning plant residues in the soil, hence the observed decrease in soil $\mathrm{pH}$ in some studies. However, laboratory studies carried out on contaminated soil in South Africa show that soil $\mathrm{pH}$ increases with increase in temperature up to $150{ }^{\circ} \mathrm{C}$, after which there is no obvious effect of fire on soil pH (Figure 3a) [44]. These changes were observed after up to about $4 \mathrm{~h}$ of heating at various temperatures (Figure $3 \mathrm{~b}-\mathrm{e}$ ). The values obtained in this study are similar to those reported by Arocena and Opio [16] in burnt soils. These results highlight the role of fire intensity and duration on the changes in soil $\mathrm{pH}$ observed during fire events. Combustion of organic matter and ash production which releases large quantities of base forming ions calcium (Ca), magnesium $(\mathrm{Mg})$ and potassium $(\mathrm{K})$ during burning is the main explanation used to justify the increase in $\mathrm{pH}$ values observed with increase in fire intensity and duration. Granged et al. [72], Arocena and Opio [16], and Úbeda et al. [74] have all shown that changes in soil pH caused by fires only last for about 3 years though Etiégni and Campbell [75] reported up to 50 years.

Soil $\mathrm{pH}$ is one of the major properties influencing the soil sorption complex. This role is associated with the fact that some charges in soils are $\mathrm{pH}$-dependent and their contribution to the overall soil sorption capacity would vary with $\mathrm{pH}$. The charges carried by organic matter and some clay minerals like kaolinite are $\mathrm{pH}$-dependent, with increase in $\mathrm{pH}$ resulting in increased density of negative charges on these components, and vice versa. Increase in soil $\mathrm{pH}$ could therefore result in an increase in the density of negative charges on the soil and consequently their sorption capacity. However, fires reduce soil organic matter content, and so changes in $\mathrm{pH}$ may have no effect on the fraction of soil CEC contributed by organic matter because the functional groups contained in soil organic matter would have been destroyed or transformed. No correlation was observed between $\mathrm{pH}$ and CEC of soils in a laboratory study by Ngole-Jeme [44] (Figure 4), which indicate that the reduction in CEC with heating of soils may have been due to changes in the lattice structure of the mineral components of the soil particles rather than by $\mathrm{pH}$-dependent charges on the organic matter fraction of the soil. This further highlights the complexity of soil sorption. In minerals like kaolinite with hydroxyl groups on their outer edges, increase in $\mathrm{pH}$ would increase the negative charges on the mineral, which in turn will affect the CEC of the soil, and consequently its sorption capacity. This would be possible only 
if the soil temperature was not high enough to alter the structural composition of the kaolinite and consequently its surface charge density. Conversion of kaolinite to primary minerals during fires of high intensity would also mean that fire-induced changes in $\mathrm{pH}$ may not have any effect on the fraction of soil sorption contributed by the $\mathrm{pH}$-dependent charges on kaolinite. Changes in soil $\mathrm{pH}$ caused by fire events could therefore either reduce or increase soil sorption capacity, depending on the content of organic matter in the soil, the presence of minerals with $\mathrm{pH}$-dependent charges, and soil temperature.

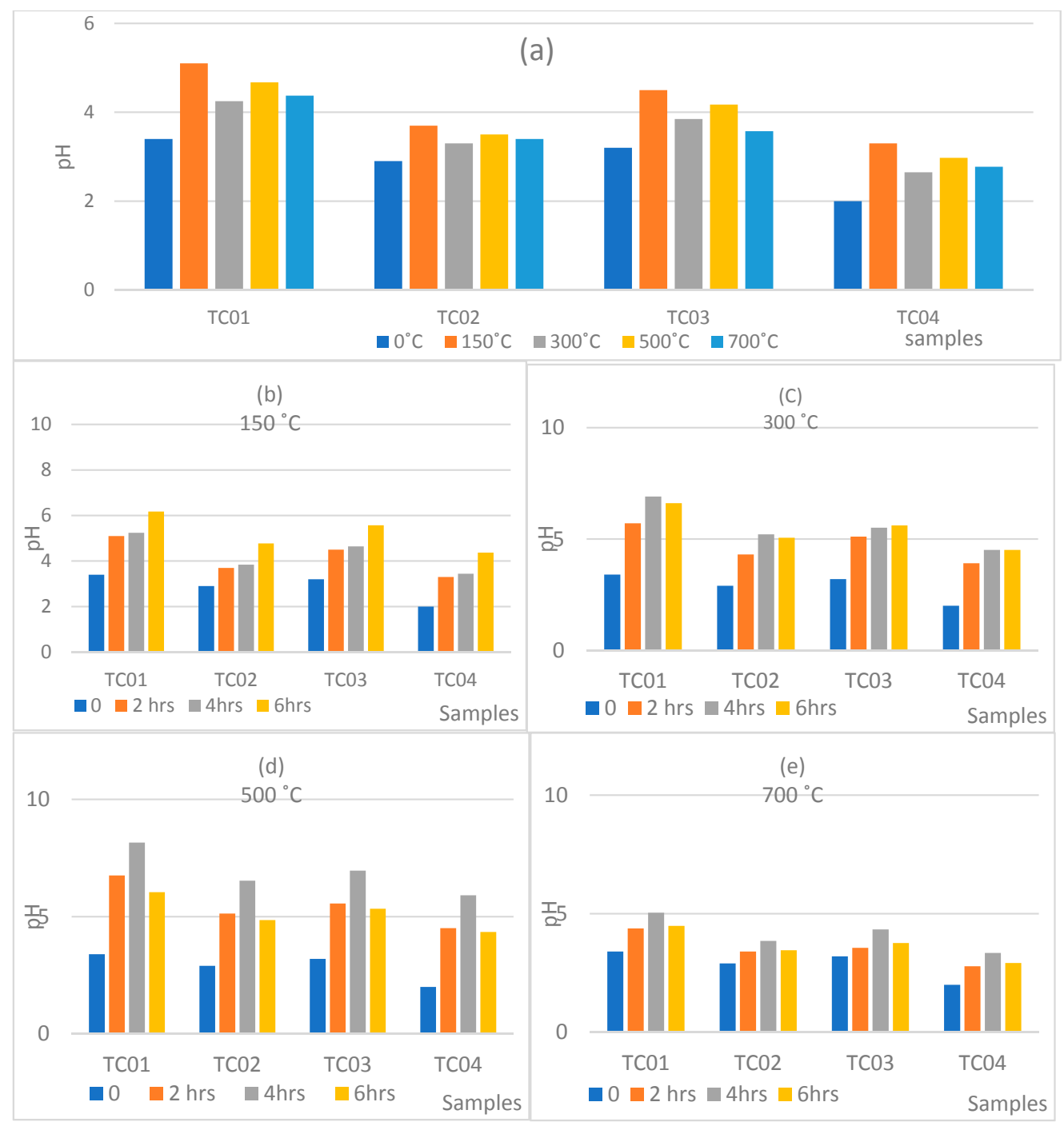

Figure 3. Variation of soil $\mathrm{pH}$ with intensity and duration of heating.

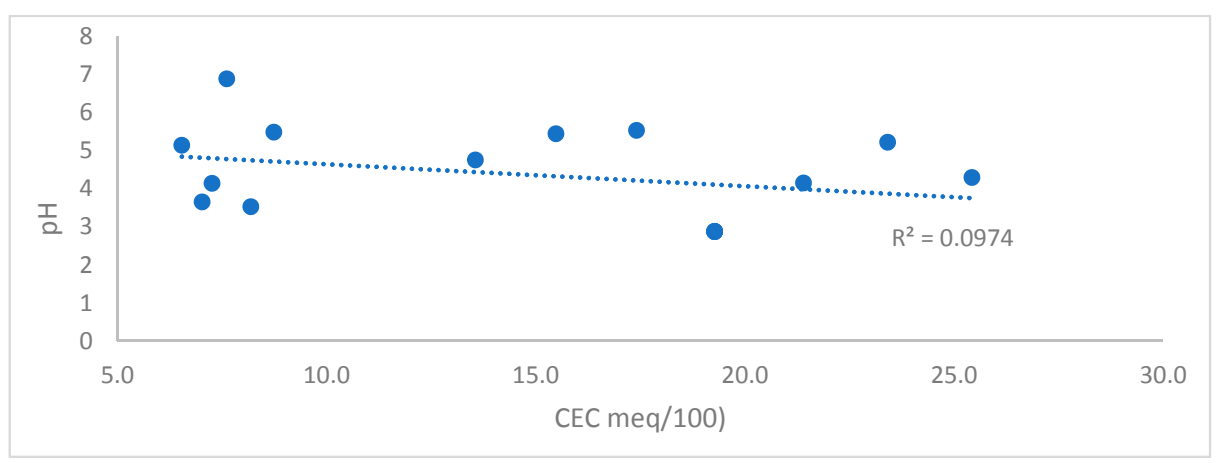

Figure 4. Relationship between $\mathrm{pH}$ and CEC of soils heated at different temperatures. 


\section{Fire-Induced Changes in Soil and Choice of Soil Remediation Technologies}

Soil remediation involves processes which restore the soil to its original condition before contamination [133]. The effectiveness of soil remediation technologies is dependent on the right conditions in the soil environment. Five mechanisms including biodegradation, sorption, dilution, chemical reactions and evaporation are employed in the cleanup of contaminated soils [134]. These technologies have been exploited by humans in the development of various physical, chemical, and biological methods used to clean contaminated soil. The effectiveness of these methods in soil remediation vary from site to site and with contaminant type according studies reported in literature. Physical remediation methods for example are applicable on small sites because of the cost of replacing or importing soil. The effectiveness of technologies which involve the use of heat to degrade or volatilize contaminants may be low or negligible in soils which have already been subjected to heat, like mine tailings contaminated soils. Fire-affected soils have been subjected to heat, and so remediation methods like vitrification and thermal desorption, which require volatilization of the contaminants in the soil, may not be effective in fire-affected soils that have experienced temperatures above $500{ }^{\circ} \mathrm{C}$. The use of biological methods requires the presence of microorganisms and conditions that support their growth in the contaminated environments. Bioremediation may be effective only after some modification of the contaminated site. In this section, the remediation methods that could be used on fire-affected soils and how they could be optimized to improve efficiency are discussed.

\subsection{Physical Remediation Technologies That Could be Used in Fire-Affected Soils}

\subsubsection{Soil Replacement, Isolation and Importing}

Soil replacement involves replacing contaminated soil with clean soil [135], whereas in soil importing, clean soil is added to contaminated soil and homogenized to reduce contaminant concentration per gram of soil. The cost and logistics of excavating and transporting soil could be huge, and so soil replacement can only be feasible if the area contaminated is small. The principle behind soil importing is dilution. Considering the cost involved, these remediation technologies are feasible where the contaminated area is spacious, to allow access to excavators, and where the area of the contaminant plume is small and shallow, to reduce the cost of excavation and transportation. In soil isolation, contaminant spread is prevented by isolating the contaminated site using various barriers, which could be vertically or horizontally placed depending on the nature of contamination, the characteristics of the site, and the contaminants in question [136]. In soil isolation, the contaminant is neither removed nor treated, but its mobility to other environmental receptors is restricted. Soil replacement, soil isolation and soil importing are physical processes which do not require chemical or biological reactions to clean up contaminated soils. They could therefore be used to remediate fire-affected contaminated soils if the contaminated site is spacious and the contaminant plume has not spread extensively.

\subsubsection{Electrokinetic Remediation}

Electrokinetic remediation has been widely used to treat heavy metals, organic compounds, and radionuclide contaminated soil and sediments with low permeability and high heterogeneity [135,137]. It is based on the principle that an electric field of suitable intensity established on a contaminated site where a pair of electrodes has been installed can attract contaminants through electroosmosis, electrophoresis or electromigration [138], separating them from the soil [136]. According to Khalid et al. [136], if the contaminants involved are poor conductors, preliminary dissolution of the contaminant using an appropriate electrolyte like distilled water, organic acids or synthetic chelates may be required to improve contaminant removal efficiency during electrokinetic remediation. Distilled water may not be a good electrolyte for dissolution of contaminants in fire-affected soils because of the apparent hydrophophobicity of particles in such soils. An compound which is capable of breaking the hydrophobicity of the soil particles would be appropriate as an electrolyte. The prevailing $\mathrm{pH}$ and electrical conductivity of the site is also a concern in electrokinetic remediation. Soil $\mathrm{pH}$ according to 
Wang et al. [139] is the main limiting factor in direct soil remediation using electrokinesis, possibly because contaminant speciation is $\mathrm{pH}$-dependent. This is overcome by adding $\mathrm{pH}$ buffer solutions to the anode and cathode using a complexant or ion exchange membrane. The extent of $\mathrm{pH}$ changes experienced after adding a $\mathrm{pH}$ buffer would depend on the soil's buffering capacity which in itself is determined by the level of exchangeable and residual acidity in the soil. Soil organic matter plays a significant role in the level of soil exchangeable acidity. Fire-induced changes in soil pH and organic matter content may therefore influence the amount of buffer required to bring the $\mathrm{pH}$ to an appropriate level to improve the efficiency of contaminant removal during electrokinetic remediation. Electrokinetic remediation could therefore be used on fire-affected contaminated soils if an appropriate electrolyte is used for contaminant dissolution and the right $\mathrm{pH}$ for migration of the contaminants between the electrodes are achieved.

\subsection{Chemical Remediation Methods}

\subsubsection{Chemical Leaching}

Chemical leaching uses fresh water, reagents and other fluids and or gases to wash contaminated soil in order to leach out contaminants $[140,141]$. Fire-affected soils are usually hydrophobic because of the transformation of functional groups in soil organic matter. This may render leaching of contaminants in fire-affected soils with water ineffective. Chemical leachates used in soil washing could be inorganic eluent, chelation agents, and surfactant, which may include hydrogen fluoride, phosphoric acid, sulfuric acid, hydrogen chloride, nitric acid, ethylenediaminetetraacetic acid (EDTA) acetone, hexane, chlorinated solvents, triethylamine, liquefied propane, and supercritical carbon dioxide. The specific chemical used for leaching varies with contaminant and hydrophobicity of the soil. The contaminants are transferred from soil solid to the liquid phase (leachate), using either adsorption, chelation, ion exchange or precipitation from where they could be recovered, or the leachate treated as hazardous wastewater. These chemical processes require specific conditions for them to be successful. The efficiency of soil remediation using chemical leaching varies. Removal efficiencies of $70 \%, 30 \%, 25 \%$ and $10 \%$ have been reported for $\mathrm{Cd}, \mathrm{Zn}, \mathrm{Cr}$ and $\mathrm{Pb}$ in contaminated unburnt soils [142]. In fire-affected soils, contaminants bound to the oxidizable phase (organic matter) of the soil are liberated as a result of the transformation of organic matter by heat from the fire. The amount of bioavailable contaminants in fire-affected soil could be high, making chemical leaching a possible remediation technology for such soils. However, the choice of leaching solution plays a major role in the use of this method in fire-affected soils. In studies by Nejad et al. [143], chemical leaching has been reported to reduce Cd concentration in soils by up to $85 \%$ using $\mathrm{FeCl}_{3}$. Phosphoric acid has been identified as the most promising extractant of heavy metals in contaminated soil with leaching efficiencies of up to $99.9 \%$ in arsenic contaminated soils [143].

\subsubsection{Chemical Fixation}

Soil remediation using chemical fixation involves immobilizing contaminants in the soil using a variety of reagents or materials, which may include but not limited to clays, metallic oxides, biosolids, animal manures, biochar and lime [135]. Most immobilization technologies can be performed ex situ or in situ. Chemical processes involved in this technique of remediation include adsorption, chelation, precipitation, and complexation, which cause contaminants to be redistributed from solution to solid phase thereby immobilizing them in the environment. These processes are influenced by soil $\mathrm{pH}$, texture, CEC, organic matter content, mineralogical composition and types of oxides contained in the soil. Precipitation, for example, is favored under alkaline $\mathrm{pH}$ conditions. Remediation methods which are based on precipitation of the contaminants could be effective on fire-affected soils because of the prevailing alkaline $\mathrm{pH}$ conditions. Methods which exploit soil sorption capacity may be enhanced in fire-affected soils where biochar is produced. The sorption capacity of biochar has been widely published and is attributed to complexation of contaminants, especially heavy metals 
with alkylated and anomeric carbons, aromatic structures and aromatic C-O groups it contains. When added to soils, biochar interacts with plant roots, soil organic matter and microorganisms to form an organo-mineral-biochar complex because of its reducing nature and electrochemical properties [143]. The efficiency of biochar in the immobilization of contaminants in fire-affected soils may be negatively affected by the low organic matter content and microbial population commonly found in fire-affected soils, especially if remediation occurs soon after the fire event.

The use of organic amendments as chemical fixers in contaminated soil also relies on the interaction between these amendments and soil mineral contents to form organo-mineral complexes which increase the soil's binding capacity for various contaminants [144]. Organic amendments, especially at their initial stage of application, can immobilize heavy metal(loid)s in soil through adsorption reactions or formation of stable complexes. They contain cellulose, lignin hemicellulose, proteins, lipids, starches, simple sugars, hydrocarbons, and many other compounds with functional groups such as carbonyl, phenolic, acetamide groups, amide, amino, structural polysaccharides and esters, which have high affinity for metal complexation. Formation of organo-mineral complexes may not be possible in soils where the soil mineral assemblage has been shifted towards more inert primary minerals that are not likely to form any complexes with the added organic material. Whereas, increase in $\mathrm{pH}$ and formation of biochar in fire-affected soils may favor immobilization of contaminants in the soil, changes in soil mineralogy and texture may mobilize them. Considering that fire-affected soils have low organic matter content, use of organic amendment as contaminant immobilizers in fire-affected soil would increase organic matter content. Contaminant immobilization using organic amendment may therefore be a suitable method of remediating fire-affected soils, because it will also improve soil organic matter content, tilth, water retention capacity, and microbial population and its overall functionality in the ecosystem.

\subsubsection{Encapsulation}

Encapsulation as a remediation method involving mixing contaminated soil with concrete, lime or asphalt to immobilize the soil, preventing spread of the contamination [136]. Recent studies have also highlighted the potential of metallic nanoparticles of Fe [145], Co [146], and Ni [147] for use as encapsulators because of their unusual magnetic, optical, and electrochemical properties and chemical catalytic activities. $\mathrm{pH}$-dependent precipitation, redox-controlled precipitation of insoluble compounds, sorption potential, and incorporation into crystalline components are some mechanisms involved in the interaction between soil, contaminants contained in the soil and binder used for encapsulation. This method is similar to soil isolation except for the fact that in encapsulation, the whole contaminated soil volume is immobilized. The choice of material used for encapsulation varies with the type of contaminant. In heavy metal contaminated soil, cement is commonly used because of its high $\mathrm{pH}$ which is able to precipitate the metals. Polyvinyl alcohol, chitosan, alginate, agar, polyacrylamide and polyurethanes have been successfully used to prevent leaching of organic materials from contaminated soil by encapsulation [148]. Successful use of encapsulation to remediate fire-affected soils may depend on the material used for encapsulation because of the prevailing $\mathrm{pH}$ condition of the soil after the fire event and the expected use of the encapsulated material.

\subsection{Biological Remediation Methods}

\subsubsection{Phytoremediation}

Phytoremediation, also referred to as botanoremediation, vegetative remediation, green remediation or agro-remediation, uses green plants to fix or adsorb contaminants from the soil environment [136]. It involves three mechanisms: phytostabilization, phytovolatilization and phytoextraction. In phytostabilization, plant roots immobilize contaminants through several methods, which may include reduced soil erosion due to stabilization of soil by plant roots, reduced leaching through upward water flow generated by plant transpiration, and decrease in runoff due to 
above-ground vegetation [136]. The contaminants accumulate in the roots of plants (phytostabilizers), or are immobilized in the rhizosphere of the plant. A main characteristic of phytostabilizers is that they are able to accumulate high levels of contaminants, especially heavy metals, from the soils in their roots, but the translocation of these metals to their aerial parts is limited. The contaminant concentration in the contaminated soil is reduced usually only around the rhizosphere of the plants involved and therefore need monitoring to ensure that optimal stabilizing conditions are maintained [135].

Phytovolatilization, which is another form of phytoremediation involves the transfer of contaminants from the soil to the atmosphere by converting them into a volatile state [135]. According to Marques et al. [149], contaminants are taken up from the soil by plants and converted into less toxic vapors which are released into the atmosphere through the process of transpiration. Examples of plants with phytovolatilization potential include Arabidopsis thaliana, Brassica juncea and Chara canescens. Mercury is the most widely studied contaminant remediated through phytovolatilization. Its presence in some mining environments may validate the use of phytovolatilization as a remediation method. Most plants, however, lack the ability to volatilize contaminants like mercury, and so plants used as phytovolatilizers are usually genetically modified to improve the mer $A$ gene, which codes for mercuric ion reductase. This enzyme is the catalyst involved in the conversion of $\mathrm{Hg}^{2+}$ to elemental mercury $(\operatorname{Hg}(0))$, a volatile, non-reactive, and less toxic form of mercury. Through this, mercury in contaminated environments can be cleaned up. A major concern with this method of remediation is what happens to the contaminant after it is released into the atmosphere, and the associated environmental and human health implications.

In phytoextraction, tolerant plants extract and accumulate contaminants from the soil, preventing them from spreading in the environment. Phytoextraction could be continuous otherwise known as natural or chemically enhanced [150]. Natural phytoextraction makes use of plants with a high ability to accumulate contaminants. Generally, plants are usually not able to sustain growth under high levels of pollution and so phytoextraction is feasible only where sites are polluted by low to moderate levels of contaminants. These plants, also called hyperaccumulators, accumulate contaminants in their shoot tissues (without showing any symptoms of toxicity) to levels far above those present in the soil or in non-accumulating plant species. According to Khalid et al. [136], hyperaccumulators must have high metal-accumulation capability in their above-ground parts, must be able to tolerate high concentrations of contaminants, and should have the ability to grow fast with high biomass and a profuse root system. More than 450 hyperaccumulating plant species from 45 families (representing less than $0.2 \%$ of all angiosperms) are known. Though most of these plants hyperaccumulate and hypertolerate only one metal contaminant, some species have the ability to tolerate more than one. In chemically enhanced phytoextraction, a chelate (usually EDTA) is applied to the contaminated soil to solubilize the contaminant which then forms a metal-chelate complex facilitating its uptake by the plant, mostly through a passive apoplastic pathway [151]. The added chelate not only increases the concentration of metal in soil solution, but it also changes the primary route of plant metal-uptake from the symplastic to the apoplastic pathway improving the amount of contaminant assimilated by the plant.

Phytoremediation requires that the plant involved (phytovolatilizers, phytostabilizers, phytoextractors) be able to grow in the contaminated environment. Fire-affected contaminated soils may not have the appropriate conditions for plant growth as a result of fire-induced changes in their properties [60]. Lack of organic matter, low nutrient content, and alkaline $\mathrm{pH}$ that may predominate such soils could hinder the establishment of plants to be used for phytoremediation. Phytoremediation as a method of cleaning fire-affected soil may therefore pose challenges related to the establishment of the plants, except the soils are amended to meet the necessary conditions for plant growth. The concentrations of plants nutrient like $\mathrm{Ca}, \mathrm{K}$, and $\mathrm{Mg}$ in fire-affected soils may be high because they would have been liberated from organic matter during the fire. Considering their high temperature thresholds, they are not likely to be affected by fire, and would be available to plants in fire-affected soil. Addition of organic amendments to these soils would not only improve the 
soil organic matter content but may also influence the soil-plant-water relationship, soil tilth and the concentrations of other major plant nutrients. These changes could enhance plant growth conditions, improving the efficiency of phytoremediation.

\subsubsection{Bioremediation}

Bioremediation involves the use of microorganisms to alter contaminant migration or transformation in the soil environment through extracellular complexation, precipitation, oxidation-reduction reaction and intracellular accumulation [135,152]. Though these methods are mainly used to treat soils contaminated with organic pollutants, they have also been successfully used to treat soils contaminated with heavy metals $[135,152]$. Biodegradation is a natural process occurring in most contaminated environments and is often referred to as natural attenuation. The natural rate of this process is very slow, and so the contaminated environment is usually enhanced to improve its natural attenuation capacity. Methods of enhancements could be in situ (bioventing, biostimulation, bioaugmentation) or ex situ (biopilling, landfarming and bioreactor) $[153,154]$. Bioremediation methods like bioventing, which require the presence of autochthonous population of microorganisms capable of breaking down the contaminants in the soil [153,154], would be ineffective on fire-affected soils, because most if not all of these microorganisms would have been eliminated by the fire. Biostimulation involves addition of nutrients to the contaminated site to improve the metabolic activities of indigenous microorganisms, thereby accelerating the rate of degradation of contaminants [155]. Biodegradation of contaminants by soil microbes is limited by nutrients, $\mathrm{pH}$, temperature, moisture, oxygen, soil properties and contaminant presence. Improving these conditions in the soil environment would improve the rate of contaminant degradation and transformation by microbes in the soil environment. Biostimulation also requires the presence of autochthonous microorganisms at the contaminated site. It has been used to treat organic soil pollutants including polyaromatic hydrocarbons, non-halogenated volatile organic compounds, and petroleum in soils and aquifers but has been rarely used in the remediation of heavy metal-contaminated soil [156]. On its own, it may not be suitable as a remediation method for fire-affected soils, where the population of microorganisms would have been drastically reduced by the fire. However, if combined with bioaugmentation to ensure the presence of suitable microorganisms to act on the contaminant, biostimulation could be effective on fire-affected soils.

Bioaugmentation of the soil involves the introduction of microorganisms capable of degrading the contaminant of concern in the contaminated environment to enhance natural attenuation at the site [153]. A major challenge with this method would be the establishment of the inoculated bacteria at the site, especially if it is not adapted to the new environment. Considering that this method does not rely on autochthonous microorganisms, it could be used to treat fire-affected soils after they have been biostimulated. Fire events also destroy soil organic matter from which most microbes derive the necessary energy. To ensure the survival of the inoculated microbes in the contaminated soil, soil conditions would have to be optimized by providing the necessary $\mathrm{pH}$ and nutrient levels that support their growth.

Biopilling is an ex situ bioremediation technique that could also be used to treat fire-affected soil. In biopilling, contaminated soils are excavated after which, nutrients are added, followed by aeration to enhance microbial activities $[153,157]$. The involvement of excavation in this method implies it is practical when the volume of contaminated soil is small. Another ex situ remediation method involves using a bioreactor in which contaminated samples are fed. The reaction conditions in the bioreactor are manipulated to optimize bioremediation time. According to Azubuike et al. [153], process parameters in the bioreactor including temperature, $\mathrm{pH}$, agitation and aeration rates, substrate and inoculum concentration, nutrient content can be easily controlled to enhance bioremediation through bioreactors. This could also be used in the treatment of fire-affected soils as the inherent soil properties can be modified to meet the requirements for treatment. The volume of soil that could be treated using a bioreactor is also limited. Landfarming, another ex situ remediation technique, involves excavation or tilling of polluted soils. The excavated polluted soil is spread on a fixed layer above the ground 
to allow aerobic degradation of pollutant by autochthonous microorganisms [158]. Through tillage, the contaminated soil is aerated, nutrients are introduced, and the soil can be irrigated to stimulate the activities of autochthonous microorganisms. This method requires the presence of autochthonous microorganisms in the soil and may not be an appropriate bioremediation technique for fire-affected soils, since most of the microorganisms would have been eliminated by the fire, but it could be practiced in combination with biostimulation and bioaugmentation.

\section{Selection of Remediation Technologies to Use on Fire-Affected Soils}

Not all soil remediation technologies could be used on fire-affected soils. Based on the available literature, some physical, chemical and biological remediation technologies that could be used on such soil, and the conditions under which they could be used, are presented in Figure 5. For each of these methods, certain conditions need to be met to achieve any level of success. High water repellency, low cation exchange capacity, and prevailing high $\mathrm{pH}$ are some of the conditions in fire-affected soils which impinge on the success of these remediation technologies.

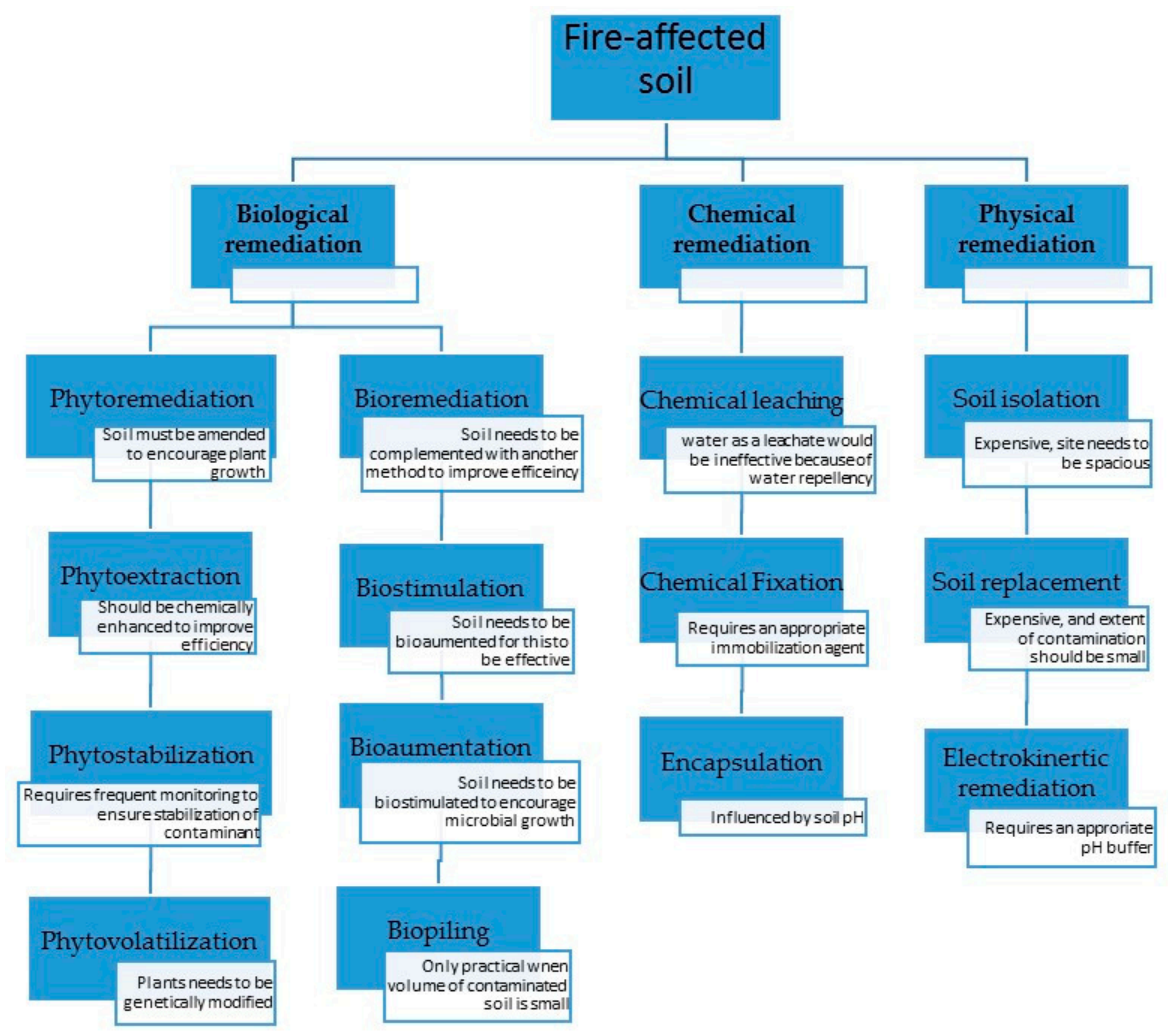

Figure 5. Remediation technologies that could be used on fire-affected soils.

\section{Conclusions}

Fire-induced changes experienced by soil texture, $\mathrm{pH}$, mineralogy, organic matter content and CEC affect soil sorption capacity and influence remediation technologies through their influence on the main reaction mechanisms employed in soil remediation. Most physical remediation methods could be effective in cleaning fire-affected soils, but those which involve exposing the contaminated soil to high temperatures need to consider the temperature to which the soil was raised during the fire event. Effective use of chemical and biological remediation methods on fire-affected soils may require modifications of certain soil chemical and biological properties including provision of a suitable population of required microbes, improvement of soil nutrient and $\mathrm{pH}$ conditions to meet the requirements of the different methods. On fire-affected soil, a combination of remediation technologies may be required because the changes that have taken place in the soil would affect the efficiency of most 
methods, especially the bioremediation methods if used in isolation. Proper identification of methods that would complement each other to achieve higher soil clean-up is required. The recommendation of remediation methods for a fire-affected soil therefore needs to consider the fire-induced changes which have occurred in the soil.

Funding: This research was funded by National Research Foundation (NRF) South Africa, Grant number 105445 and "The APC was funded by Directorate, Research Support, University of South Africa (UNISA).

Conflicts of Interest: The author declares no conflict of interest.

\section{References}

1. Huang, Y.; Wu, S.; Kaplan, J.O. Sensitivity of global wildfire occurrences to various factors in the context of global change. Atmos. Environ. 2015, 121, 86-92. [CrossRef]

2. Marlon, J.R.; Bartlein, P.J.; Carcaillet, C.; Gavin, D.G.; Harrison, S.P.; Higuera, P.E.; Joos, F.; Power, M.J.; Prentice, I.C. Climate and human influences on global biomass burning over the past two millennia. Nat. Geosci. 2008, 1, 697-702. [CrossRef]

3. Wang, Z; Chappellaz, J.; Park, K.; Mak, J.E. Large variations in southern hemisphere biomass burning during the last 650 years. Science 2010, 330, 1663-1666. [CrossRef] [PubMed]

4. North, M.P.; Stephens, S.L.; Collins, B.M.; Agee, J.K.; Aplet, G.; Franklin, J.F.; Fulé, P.Z. Reform forest fire management. Science 2015, 349, 1280-1281. [CrossRef]

5. Giglio, L.; Randerson, J.T.; van der Werf, G.R. Analysis of daily, monthly, and annual burned area using the fourth-generation global fire emissions database (gfed4). J. Geophys. Res. Biogeosci. 2013, 118, 317-328. [CrossRef]

6. Plucinski, M.P. A Review of Wildfire Occurrence Research; CSIRO: East Melbourne, Australia, 2012; pp. 1-28.

7. Cochrane, M.A. Synergistic interactions between habitat fragmentation and fire in evergreen tropical forests. Conserv. Biol. 2002, 15, 1515-1521. [CrossRef]

8. Lewis, S.L.; Edwards, D.P.; Galbraith, D. Increasing human dominance of tropical forests. Science 2015, 349, 827-832. [CrossRef] [PubMed]

9. Pfeiffer, M.; Spessa, A.; Kaplan, J.O. A model for global biomass burning in preindustrial time: Lpj-lmfire (v1.0). Geosci. Model Dev. 2013, 6, 643-685. [CrossRef]

10. Santín, C.; Doerr, S.H. Fire effects on soils: The human dimension. Philos. Trans. R. Soc. B Biol. Sci. 2016, 371, 20150171. [CrossRef] [PubMed]

11. José Martínez-Sánchez, J.; Ferrandis, P.; de las Heras, J.; María Herranz, J. Effect of burnt wood removal on the natural regeneration of pinus halepensis after fire in a pine forest in tus valley (se spain). For. Ecol. Manag. 1999, 123, 1-10. [CrossRef]

12. Vihnanek, R.E.; Ballard, T.M. Slashburning effects on stocking, growth, and nutrition of young douglas-fir plantations in salal-dominated ecosystems of eastern vancouver island. Can. J. For. Res. 1988, 18, 718-722. [CrossRef]

13. Caldararo, N. Human ecological intervention and the role of forest fires in human ecology. Sci. Total. Environ. 2002, 292, 141-165. [CrossRef]

14. Scharenbroch, B.C.; Nix, B.; Jacobs, K.A.; Bowles, M.L. Two decades of low-severity prescribed fire increases soil nutrient availability in a midwestern, USA oak (quercus) forest. Geoderma 2012, 183-184, 80-91. [CrossRef]

15. Kennard, D.K.; Gholz, H.L. Effects of high- and low-intensity fires on soil properties and plant growth in a bolivian dry forest. Plant Soil 2001, 234, 119-129. [CrossRef]

16. Arocena, J.M.; Opio, C. Prescribed fire-induced changes in properties of sub-boreal forest soils. Geoderma 2003, 113, 1-16. [CrossRef]

17. De Marco, A.; Gentile, A.E.; Arena, C.; De Santo, A.V. Organic matter, nutrient content and biological activity in burned and unburned soils of a mediterranean maquis area of southern italy. Int. J. Wildland Fire 2005, 14, 365-377. [CrossRef]

18. Mbalo, B.A.; Witkowski, E.T.F. Tolerance to soil temperatures experienced during and after the passage of fire in seeds of acacia karroo, a. Tortilis and chromolaena odorata: A laboratory study. South Afr. J. Bot. 1997, 63, 421-425. [CrossRef]

19. Hardison, J.R. Fire and flame for plant disease control. Annu. Rev. Phytopathol. 1976, 14, 355-379. [CrossRef] 
20. Alcañiz, M.; Outeiro, L.; Francos, M.; Úbeda, X. Effects of prescribed fires on soil properties: A review. Sci. Total. Environ. 2018, 613-614, 944-957. [CrossRef] [PubMed]

21. Cleland, D.T.; Brosofske, K.D.; Saunders, S.C. Factors influencing modern wildfire occurrence in the mark twain national forest, missouri. South. J. Appl. For. 2007, 31, 73-84.

22. Cruz, G.M.; Gould, S.J.; Hollis, J.J.; McCaw, L.W. A hierarchical classification of wildland fire fuels for australian vegetation types. Fire 2018, 1, 13. [CrossRef]

23. Ohlemiller, T.J. Modeling of smoldering combustion propagation. Prog. Energy Combust. Sci. 1985, 11, 277-310. [CrossRef]

24. Rein, G. Smouldering combustion phenomena in science and technology. Int. Rev. Chem. Eng. 2009, 1, 3-18.

25. Rein, G.; Garcia, J.; Simeoni, A.; Tihay, V.; Ferrat, L. Smouldering natural fires: Comparison of burning dynamics in boreal peat and mediterranean humus. WIT Trans. Ecol. Environ. 2008, 119, 183-192.

26. Certini, G. Effects of fire on properties of forest soils: A review. Oecologia 2005, 143, 1-10. [CrossRef]

27. Fares, S.; Bajocco, S.; Salvati, L.; Camarretta, N.; Dupuy, J.-L.; Xanthopoulos, G.; Guijarro, M.; Madrigal, J.; Hernando, C.; Corona, P. Characterizing potential wildland fire fuel in live vegetation in the mediterranean region. Ann. For. Sci. 2017, 74, 1. [CrossRef]

28. Badía, D.; López-García, S.; Martí, C.; Ortíz-Perpiñá, O.; Girona-García, A.; Casanova-Gascón, J. Burn effects on soil properties associated to heat transfer under contrasting moisture content. Sci. Total. Environ. 2017, 601-602, 1119-1128. [CrossRef]

29. Stoof, C.R.; Moore, D.; Fernandes, P.M.; Stoorvogel, J.J.; Fernandes, R.E.; Ferreira, A.J.; Ritsema, C.J. Hot fire, cool soil. Geophys. Res. Lett. 2013, 40, 1534-1539. [CrossRef]

30. Keeley, J.E. Fire intensity, fire severity and burn severity: A brief review and suggested usage. Int. J. Wildland Fire 2009, 18, 116-126. [CrossRef]

31. Reynard-Callanan, J.R.; Pope, G.A.; Gorring, M.L.; Feng, H. Effects of high-intensity forest fires on soil clay mineralogy. Phys. Geogr. 2010, 31, 407-422. [CrossRef]

32. Janzen, C.; Tobin-Janzen, T. Microbial communities in fireaffected soils. In Microbiology of Extreme Soils, Soil Biology; Dion, P., Nautiyal, C.S., Eds.; Springer: Berlin/Heidelberg, Germany, 2008; Volume 13.

33. Waldrop, T.A.; Brose, P.H. A comparison of fire intensity levels for stand replacement of table mountain pine (pinus pungens lamb.). For. Ecol. Manag. 1999, 113, 155-166. [CrossRef]

34. Humphreys, F.R.; Craig, F.G. Effects of Fire on Soil Chemical, Structural and Hydrological Properties; Australian Academy of Science: Canberra, Australia, 1981; p. 124.

35. Korfmacher, J.L.; Chambers, J.C.; Tausch, R.J.; Roundy, B.A.; Meyer, S.E.; Stanley, K. Technical note: A technique for conducting small-plot burn treatments. J. Range Manag. 2003, 56, 251-254. [CrossRef]

36. Neary, D.G.; Klopatek, C.C.; DeBano, L.F.; Ffolliott, P.F. Fire effects on belowground sustainability: A review and synthesis. For. Ecol. Manag. 1999, 122, 51-71. [CrossRef]

37. Bates, J.D.; Davies, K.W.; Sharp, R.N. Shrub-steppe early succession following juniper cutting and prescribed fire. Environ. Manag. 2011, 47, 468-481. [CrossRef] [PubMed]

38. Úbeda, X.; Outeiro, L. Physical and Chemical Effects of Fire on Soil; Science Publishers, Inc.: Enfield, NH, USA, 2009.

39. Velasco, A.Y.O. Efecto del Fuego en los Campos de Caña; Academia de Ciencias de Cuba: La Habana, Cuba, 1968; Volume 4.

40. Cesar, H.L. Efeitos da Quema e Corte Sobre a Vegetacao de um Campo Sujo na Fazenda Agua Limpa-df; University of Brazil: São Paulo, Brazil, 1980.

41. Cawson, J.; Sheridan, G.; Smith, H.; Lane, P. Surface runoff and erosion after prescribed burning and the effect of different fire regimes in forests and shrublands: A review. Int. J. Wildland Fire 2012, 21, 857-872. [CrossRef]

42. Bova, A.S.; Dickinson, M.B. Linking surfacefire behavior, stem heating, and tissue necrosis. Can. J. For. Res. 2005, 35, 814-822. [CrossRef]

43. McArthur, A.G.; Cheney, N.P. The characterization of fires in relation to ecological studies, with an introduction by neil burrows. J. Assoc. Fire Ecol. 2015, 11, 1-9. [CrossRef]

44. Ngole-Jeme, V.M. Changes in the mineralogy and geochemistry of mine tailings contaminated soil as a result of fire events and the implications on soil sorption properties. In Proceedings of the 2017 International Conference on Environmental Pollution Control, Vancouver, BC, Canada, 8-12 October 2017; International Society for Environmental Sciences: Regina, SK, Canada, 2017. 
45. Nikiforova, T.; Savytskyi, M.; Limam, K.; Bosschaerts, W.; Belarbi, R. Methods and results of experimental researches of thermal conductivity of soils. Energy Procedia 2013, 42, 775-783. [CrossRef]

46. Yun, T.S.; Santamarina, J.C. Fundamental study of thermal conduction in dry soils. Granul. Matter 2007, 10, 197. [CrossRef]

47. Nusier, O.; Abu-Hamdeh, N. Laboratory techniques to evaluate thermal conductivity for some soils. Heat Mass Transf. 2003, 39, 119-123. [CrossRef]

48. Mataix-Solera, J.; Doerr, S.H. Hydrophobicity and aggregate stability in calcareous topsoils from fire-affected pine forests in southeastern spain. Geoderma 2004, 118, 77-88. [CrossRef]

49. Badía, D.; Martí, C. Plant ash and heat intensity effects on chemicaland physical properties of two contrasting soils. Arid. Land Res. Manag. 2003, 17, 23-41. [CrossRef]

50. Zihms, S.G.; Switzer, C.; Karstunen, M.; Tarantino, A. Understanding the Effects of high temperature processes on the engineering properties of soils. In Proceedings of the 18th International Conference on Soil Mechanics and Geotechnical Engineering, Paris, France, 2-6 September 2013; pp. 3427-3430.

51. Araya, S.N.; Meding, M.; Berhe, A.A. Thermal alteration of soil physico-chemical properties: A systematic study to infer response of sierra nevada climosequence soils to forest fires. Soil 2016, 2, 351-366. [CrossRef]

52. Midttømme, K.; Roaldset, E.; Aagaard, P. Thermal conductivity claystones and mudstones of selected from england. Claymin 1998, 33, 131-145. [CrossRef]

53. Giovannini, G.; Lucchesi, S.; Giachetti, M. Effect of heating on some physical and chemical parameters related to soil aggregation and erodibility. Soil Sci. 1988, 146, 255-261. [CrossRef]

54. Mehdi, H.; Ali, S.; Ali, M.; Mostafa, A. Effects of different fire severity levels on soil chemical and physical properties in zagros forests of western iran. Folia For. Pol. 2012, 54, 241-250.

55. Jõeleht, A.; Kirsimäe, K.; Shogenova, A.; Sliaupa, S.; Kukkonen, I.; Rastenienè, V.; Zabele, A. Thermal conductivity of cambrian siliciclastic rocks from the baltic basin. Proc. Estonian Acad. Sci. Geol. 2002, 51, 5-15.

56. Doerr, S.H.; Llewellyn, C.T.; Douglas, P.; Morley, C.P.; Mainwaring, K.A.; Haskins, C.; Johnsey, L.; Ritsema, C.J.; Stagnitti, F.; Allinson, G.; et al. Extraction of compounds associated with water repellency in sandy soils of different origin. Soil Res. 2005, 43, 225-237. [CrossRef]

57. Dekker, L.W.; Oostindie, K.; Ritsema, C.J. Exponential increase of publications related to soil water repellency. Aust. J. Soil Res. 2005, 43, 403-441.

58. Zavala, L.M.; Granged, A.J.P.; Jordán, A.; Bárcenas-Moreno, G. Effect of burning temperature on water repellency and aggregate stability in forest soils under laboratory conditions. Geoderma 2010, 158, 366-374. [CrossRef]

59. Bryant, R.; Doerr, S.H.; Helbig, M. Effect of oxygen deprivation on soil hydrophobicity during heating. Int. J. Wildland Fire 2005, 14, 449-455. [CrossRef]

60. DeBano, L.F. The role of fire and soil heating on water repellency in wildland environments: A review. J. Hydrol. 2000, 231-232, 195-206. [CrossRef]

61. Zavala, L.M.; De Celis, R.; JordÁN, A. How wildfires affect soil properties. A brief review. Geogr. Res. Lett. 2014, 40, 311-331. [CrossRef]

62. Letey, J. Causes and consequences of fire-induced soil water repellency. Hydrol. Process. 2001, 15, $2867-2875$. [CrossRef]

63. Stavi, I.; Barkai, D.; Knoll, Y.M.; Glion, H.A.; Katra, I.; Brook, A.; Zaady, E. Fire impact on soil-water repellency and functioning of semi-arid croplands and rangelands: Implications for prescribed burnings and wildfires. Geomorphology 2017, 280, 67-75. [CrossRef]

64. DeBano, L.F.; Krammes, J.S. Water repellent soils and their relation to wildfire temperatures. Hydrol. Sci. J. 1966, 11, 14-19. [CrossRef]

65. MacDonald, L.H.; Huffman, E.L. Post-fire soil water repellency. Soil Sci. Soc. Am. J. 2004, 68, 1729-1734. [CrossRef]

66. Ulery, A.L.; Graham, R.C. Forest fire effects on soil color and texture. Soil Sci. Soc. Am. J. 1993, 57, $135-140$. [CrossRef]

67. Ketterings, Q.M.; Bigham, J.M.; Laperche, V. Changes in soil mineralogy and texture caused by slash-and-burn fires in sumatra, indonesia. Soil Sci. Soc. Am. J. 2000, 64, 1108-1117. [CrossRef]

68. Neary, D.G.; Ryan, K.C.; DeBano, L.F. Wildland Fire in Ecosystems: Effects of Fire on Soils and Water; U.S. Department of Agriculture, Forest Service, Rocky Mountain Research Station: Ogden, UT, USA, 2005; Volume 4, p. 250. 
69. Begum, A.; Ramaiah, M.; Khan, I.; Veena, K. Heavy metal pollution and chemical profile of cauvery river water. E-J. Chem. 2009, 6, 47-52. [CrossRef]

70. Xue, L.; Li, Q.; Chen, H. Effects of a wildfire on selected physical, chemical and biochemical soil properties in a pinus massoniana forest in south china. Forests 2014, 5, 2947-2966. [CrossRef]

71. Ponder, F.; Tadros, M.; Loewenstein, E.F. Microbial properties and litter and soil nutrients after two prescribed fires in developing savannas in an upland missouri ozark forest. For. Ecol. Manag. 2009, 257, 755-763. [CrossRef]

72. Granged, A.J.P.; Jordán, A.; Zavala, L.M.; Muñoz-Rojas, M.; Mataix-Solera, J. Short-term effects of experimental fire for a soil under eucalyptus forest (se australia). Geoderma 2011, 167-168, 125-134. [CrossRef]

73. Terefe, T.; Mariscal-Sancho, I.; Peregrina, F.; Espejo, R. Influence of heating on various properties of six mediterranean soils. A laboratory study. Geoderma 2008, 143, 273-280. [CrossRef]

74. Úbeda, X.; Lorca, M.; Outeiro, L.R.; Bernia, S.; Castellnou, M. Effects of prescribed fire on soil quality in mediterranean grassland (prades mountains, north-east spain). Int. J. Wildland Fire 2005, 14, 379-384. [CrossRef]

75. Etiégni, L.; Campbell, A.G. Physical and chemical characteristics of wood ash. Bioresour. Technol. 1991, 37, 173-178. [CrossRef]

76. Hosking, J.S. The ignition at low temperatures of the organic matter in soils. J. Agric. Sci. 1938, 28, 393-400. [CrossRef]

77. Tiedemann, A.R. Combustion losses of sulfur from forest foliage and litter. For. Sci. 1987, 33, $216-223$.

78. Raison, R.J.; Khanna, P.K.; Woods, P.V. Mechanisms of element transfer to the atmosphere during vegetation fires. Can. J. For. Res. 1985, 15, 132-140. [CrossRef]

79. Rabenhorst, M.C. Determination of organic and carbonate carbon in calcareous soils using dry combustion. Soil Sci. Soc. Am. J. 1988, 52, 965-968. [CrossRef]

80. Chandler, C.; Cheney, P.; Thomas, P.; Trabaud, L.; Williams, D. Fire in Forestry. Volume 1. Forest Fire Behavior and Effects; John Wiley \& Sons: New York, NY, USA, 1983.

81. González-Pérez, J.A.; González-Vila, F.J.; Almendros, G.; Knicker, H. The effect of fire on soil organic matter-A review. Environ. Int. 2004, 30, 855-870. [CrossRef] [PubMed]

82. Almendros, G.; Gonzalez-Vila, F.J.; Martin, F. Fire-induced transformation of soil organic matter from an oak forest: An experimental approach to the effects of fire on humic substances. Soil Sci. 1990, 149, 158-168. [CrossRef]

83. González-Vila, F.J.; Tinoco, P.; Almendros, G.; Martin, F. Pyrolysis-gc-ms analysis of the formation and degradation stages of charred residues from lignocellulosic biomass. J. Agric. Food Chem. 2001, 49, 1128-1131. [CrossRef]

84. Almendros, G.; Martín, F.; González-Vila, F.J. Effects of fire on humic and lipid fractions in a dystric xerochrept in spain. Geoderma 1988, 42, 115-127. [CrossRef]

85. González-Vila, F.J.; González, J.A.; Polvillo, O.; Almendros, G.; Knicker, H. Nature of refractory forms of organic carbon in soils affected by fires. Pyrolytic and spectroscopic approaches. In Proceedings of the IV International Conference on Forest Fire Research and Wildland Fire Safety, Rottadam, The Netherlands, 18-23 November 2002; Viegas, D.X., Ed.; Millpress: Rottadam, The Netherlands; pp. 226-230.

86. Bodí, M.B.; Martin, D.A.; Balfour, V.N.; Santín, C.; Doerr, S.H.; Pereira, P.; Cerdà, A.; Mataix-Solera, J. Wildland fire ash: Production, composition and eco-hydro-geomorphic effects. Earth-Sci. Rev. 2014, 130, 103-127. [CrossRef]

87. Kovacic, D.A.; Swift, D.M.; Ellis, J.E.; Hakonson, T.E. Immediate effects of prescribed burning on mineral soil nitrogen in ponderosa pine of new mexico. Soil Sci. 1986, 141, 71-76. [CrossRef]

88. Schoch, P.; Binkley, D. Prescribed burning increased nitrogen availability in a mature loblolly pine stand. For. Ecol. Manag. 1986, 14, 13-22. [CrossRef]

89. Covington, W.W.; Sackett, S.S. Soil mineral nitrogen changes following prescribed burning in ponderosa pine. For. Ecol. Manag. 1992, 54, 175-191. [CrossRef]

90. Bell, R.L.; Binkley, D. Soil nitrogen mineralization and immobilization in response to periodic prescribed fire in a loblolly pine plantation. Can. J. For. Res. 1989, 19, 816-820. [CrossRef]

91. Knoepp, J.D.; Swank, W.T. Comparison of available soil nitrogen assays in control and burned forested sites. Soil Sci. Soc. Am. J. 1995, 59, 1750-1754. [CrossRef] 
92. Grier, C.C. Wildfire effects on nutrient distribution and leaching in a coniferous ecosystem. Can. J. For. Res. 1975, 5, 559-607. [CrossRef]

93. DeBano, L.F.; Rice, R.M.; Conrad, C.E. Soil Heating Chaparral Fires: Effects on Soil Properties, Plant Nutrients, Erosion and Runoff; Department of Agriculture, Forest Service, Pacific Southwest Forest and Range Experiment Station: Berkeley, CA, USA, 1979; p. 21.

94. Giardina, C.P.; Rhoades, C.C. Clear cutting and burning affect nitrogen supply, phosphorus fractions and seedling growth in soils from a wyoming lodgepole pine forest. For. Ecol. Manag. 2001, 140, 19-28. [CrossRef]

95. Galang, M.A.; Markewitz, D.; Morris, L.A. Soil phosphorus transformations under forest burning and laboratory heat treatments. Geoderma 2010, 155, 401-408. [CrossRef]

96. Schaller, J.; Tischer, A.; Struyf, E.; Bremer, M.; Belmonte Dácil, U.; Potthast, K. Fire enhances phosphorus availability in topsoils depending on binding properties. Ecology 2015, 96, 1598-1606. [CrossRef]

97. Tan, K.H.; Hajek, B.F.; Barshad, I. Thermal Analysis Techniques; American Society of Agronomy and Soil Science Society of America: Madison, WI, USA, 1986.

98. Yusiharni, E.; Robert, J.G. Soil minerals recover after they are damaged by bushfires. In Proceedings of the 19th World Congress of Soil Science, Soil Solutions for a Changing World, Brisbane, Australia, 1-6 August 2010; International Union of Soil Sciences: Vienna, Austria, 2010; pp. 104-107.

99. Cornell, R.M.; Schwertmann, U. The Iron Oxides: Structure, Properties, Reactions, Occurences and Uses, 2nd ed.; Wiley-VCH Verlag GmbH \& Co. KGaA: Weinheim, Germany, 2004.

100. Frost, R.L.; Horváth, E.; Makó, É.; Kristóf, J.; Rédey, Á. Slow transformation of mechanically dehydroxylated kaolinite to kaolinite-An aged mechanochemically activated formamide-intercalated kaolinite study. Thermochim. Acta 2003, 408, 103-113. [CrossRef]

101. Richardson, H.M. Phase Changes which Occur on Heating Kaolin Clays. The $x$-Ray Identification and Crystal Structures of Clay Minerals; Minerals Society Publishing: London, UK, 1972; p. 11.

102. Prieto-Fernández, A.; Acea, M.J.; Carballas, T. Soil microbial and extractable $\mathrm{c}$ and $\mathrm{n}$ after wildfire. Biol. Fertil. Soils 1998, 27, 132-142. [CrossRef]

103. Dumontet, S.; Dinel, H.; Scopa, A.; Mazzatura, A.; Saracino, A. Post-fire soil microbial biomass and nutrient content of a pine forest soil from a dunal mediterranean environment. Soil Biol. Biochem. 1996, 28, 1467-1475. [CrossRef]

104. Dunn, P.H.; Barro, S.C.; Poth, M. Soil moisture affects survival of microorganisms in heated chaparral soil. Soil Biol. Biochem. 1985, 17, 143-148. [CrossRef]

105. Matlack, G.R. Factors determining the distribution of soil nematodes in a commercial forest landscape. For. Ecol. Manag. 2001, 146, 129-143. [CrossRef]

106. Collett, N.G.; Neumann, F.G.; Tolhurst, K.G. Effects of two short rotation prescribed fires in spring on surface-active arthropods and earthworms in dry sclerophyll eucalypt forest of west-central victoria. Aust. For. 1993, 56, 49-60. [CrossRef]

107. Kim, E.J.; Oh, J.-E.; Chang, Y.-S. Effects of forest fire on the level and distribution of pcdd/fs and pahs in soil. Sci. Total. Environ. 2003, 311, 177-189. [CrossRef]

108. Fonturbel, M.T.; Vega, J.A.; Bara, S.; Bernardez, I. influence of prescribed burning of pine stands in nw spain on soil microorganisms. Eur. J. Soil Biol. 1995, 31, 13-20.

109. Choromanska, U.; DeLuca, T.H. Prescribed fire alters the impact of wildfire on soil biochemical properties in a ponderosa pine forest. Soil Sci. Soc. Am. J. 2001, 65, 232-238. [CrossRef]

110. Thompson, A.; Goyne, K.W. Introduction to the sorption of chemical constituents in soils. Nat. Educ. Knowl. 2012, 4, 7 .

111. Kalembasa, D.; Pakuła, K.; Jaremko, D. Sorption properties of soils in the siedlce upland. Acta Agrophys. 2011, 18, 311-319.

112. Lair, G.J.; Gerzabek, M.H.; Haberhauer, G. Sorption of heavy metals on organic and inorganic soil constituents. Environ. Chem. Lett. 2007, 5, 23-27. [CrossRef]

113. Obale-Ebanga, F.; Sevink, J.; de Groot, W.; Nolte, C. Myths of slash and burn on physical degradation of savannah soils: Impacts on vertisols in north cameroon. Soil Use Manag. 2003, 19, 83-86. [CrossRef]

114. Stoof, C.R.; Wesseling, J.G.; Ritsema, C.J. Effects of fire and ash on soil water retention. Geoderma 2010, 159, 276-285. [CrossRef]

115. Heydari, M.; Rostamy, A.; Najafi, F.; Dey, D.C. Effect of fire severity on physical and biochemical soil properties in zagros oak (quercus brantii lindl.) forests in iran. J. For. Res. 2017, 28, 95-104. [CrossRef] 
116. Falciglia, P.P.; Giustra, M.G.; Vagliasindi, F.G.A. Soil texture affects adsorption capacity and removal efficiency of contaminants in ex situ remediation by thermal desorption of diesel-contaminated soils. Chem. Ecol. 2011, 27, 119-130. [CrossRef]

117. Schulten, H.R.; Leinweber, P. New insights into organic-mineral particles: Composition, properties and models of molecular structure. Biol. Fertil. Soils 2000, 30, 399-432. [CrossRef]

118. Nkedi-Kizza, P.; Rao, P.S.C.; Johnson, J.W. Adsorption of diuron and 2,4,5-t on soil particle-size separates1. J. Environ. Qual. 1983, 12, 195-197. [CrossRef]

119. Evans, K.M.; Gill, R.A.; Robotham, P.W.J. The pah and organic content of sediment particle size fractions. Water Air Soil Pollut. 1990, 51, 13-31. [CrossRef]

120. Iturri, L.A.; Buschiazzo, D.E. Cation exchange capacity and mineralogy of loess soils with different amounts of volcanic ashes. Catena 2014, 121, 81-87. [CrossRef]

121. Martín-García, J.M.; Delgado, G.; Párraga, J.F.; Gámiz, E.; Delgado, R. Chemical, mineralogical and (micro)morphological study of coarse fragments in mediterranean red soils. Geoderma 1999, 90, $23-47$. [CrossRef]

122. Rieuwerts, J.S.; Thornton, I.; Farago, M.E.; Ashmore, M.R. Factors influencing metal bioavailability in soils: Preliminary investigations for the development of a critical loads approach for metals. Chem. Speciat. Bioavailab. 1998, 10, 61-75. [CrossRef]

123. Hyun, S.; Lee, L.S.; Rao, P.S.C. Significance of anion exchange in pentachlorophenol sorption by variable-charge soils. J. Environ. Qual. 2003, 32, 966-976. [CrossRef]

124. Wang, H.; Xia, W.; Lu, P. Study on adsorption characteristics of biochar on heavy metals in soil. Korean J. Chem. Eng. 2017, 34, 1867-1873. [CrossRef]

125. Zhelezova, A.; Cederlund, H.; Stenström, J. Effect of biochar amendment and ageing on adsorption and degradation of two herbicides. Water Air Soil Pollut. 2017, 228, 216. [CrossRef]

126. Pingree, M.R.A.; DeLuca, T.H. Function of wildfire-deposited pyrogenic carbon in terrestrial ecosystems. Front. Environ. Sci. 2017, 5, 53. [CrossRef]

127. Inyang, M.I.; Gao, B.; Yao, Y.; Xue, Y.; Zimmerman, A.; Mosa, A.; Pullammanappallil, P.; Ok, Y.S.; Cao, X. A review of biochar as a low-cost adsorbent for aqueous heavy metal removal. Crit. Rev. Environ. Sci. Technol. 2016, 46, 406-433. [CrossRef]

128. Pingree, M.R.A.; DeLuca, E.E.; Schwartz, D.T.; DeLuca, T.H. Adsorption capacity of wildfire-produced charcoal from pacific northwest forests. Geoderma 2016, 283, 68-77. [CrossRef]

129. Cheng, C.-H.; Lehmann, J.; Engelhard, M.H. Natural oxidation of black carbon in soils: Changes in molecular form and surface charge along a climosequence. Geochim. Cosmochim. Acta 2008, 72, 1598-1610. [CrossRef]

130. Hammes, K.; Schmidt, M.W.I. Changes of biochar in soil. Biochar Environ. Manag. Sci. Technol. 2009, 1, 169-181.

131. Liang, B.; Lehmann, J.; Solomon, D.; Kinyangi, J.; Grossman, J.; O’Neill, B.; Skjemstad, J.O.; Thies, J.; Luizão, F.J.; Petersen, J.; et al. Black carbon increases cation exchange capacity in soils. Soil Sci. Soc. Am. J. 2006, 70, 1719-1730. [CrossRef]

132. Sherman, L.; Brye, K.R.; Gill, D.E.; Koenig, K.A. Soil Chemistry as Affected by First-Time Prescribed Burning of a Grassland Restoration on a Coastal Plain Ultisol. Soil Sci. 2005, 170, 913-927. [CrossRef]

133. Jadia, C.D.; Fulekar, M.H. Phytoremediation of heavy metals: Recent techniques. Afr. J. Biotechnol. 2009, 8, 921-928.

134. USEPA. A Citizon's Guide to Monitored Natural Attenuation; United States Environmental Protection Agency: Washington, DC, USA, 2012.

135. Yao, Z.; Li, J.; Xie, H.; Yu, C. Review on remediation technologies of soil contaminated by heavy metals. Procedia Environ. Sci. 2012, 16, 722-729. [CrossRef]

136. Khalid, S.; Shahid, M.; Niazi, N.K.; Murtaza, B.; Bibi, I.; Dumat, C. A comparison of technologies for remediation of heavy metal contaminated soils. J. Geochem. Explor. 2017, 182, 247-268. [CrossRef]

137. Yeung, A.T.; Gu, Y.-Y. A review on techniques to enhance electrochemical remediation of contaminated soils. J. Hazard. Mater. 2011, 195, 11-29. [CrossRef]

138. Alshawabkeh, A.N. Electrokinetic soil remediation: Challenges and opportunities. Sep. Sci. Technol. 2009, 44, 2171-2187. [CrossRef]

139. Wang, H.; Ma, J.; Fan, X. Research progress on enhancement of in situ remediation of heavy metal by electrokinitics. Ecol. Environ. 2007, 16, 223-227. 
140. Tampouris, S.; Papassiopi, N.; Paspaliaris, I. Removal of contaminant metals from fine grained soils, using agglomeration, chloride solutions and pile leaching techniques. J. Hazard. Mater. 2001, 84, 297-319. [CrossRef]

141. Ouyang, X.; Chen, J.W.; Zhang, X.G. Advance in supercritical $\mathrm{CO}_{2}$ fluid extraction of contaminants from soil. Geol. Bull. China 2010, 29, 1655-1661.

142. Abumaizar, R.J.; Smith, E.H. Heavy metal contaminants removal by soil washing. J. Hazard. Mater. 1999, 70, 71-86. [CrossRef]

143. Derakhshan Nejad, Z.; Jung, M.C.; Kim, K.-H. Remediation of soils contaminated with heavy metals with an emphasis on immobilization technology. Environ. Geochem. Health 2018, 40, 927-953.

144. Violante, A.; Cozzolino, V.; Perelomov, L.; Caporale, A.G.; Pigna, M. Mobility and bioavailability of heavy metals and metalloids in soil environments. J. Soil Sci. Plant Nutr. 2010, 10, 268-292. [CrossRef]

145. Park, S.-J.; Kim, S.; Lee, S.; Khim, Z.G.; Char, K.; Hyeon, T. Synthesis and magnetic studies of uniform iron nanorods and nanospheres. J. Am. Chem. Soc. 2000, 122, 8581-8582. [CrossRef]

146. Tripp, S.L.; Pusztay, S.V.; Ribbe, A.E.; Wei, A. Self-assembly of cobalt nanoparticle rings. J. Am. Chem. Soc. 2002, 124, 7914-7915. [CrossRef] [PubMed]

147. Hou, Y.; Gao, S. Monodisperse nickel nanoparticles prepared from a monosurfactant system and their magnetic properties. J. Mater. Chem. 2003, 13, 1510-1512. [CrossRef]

148. He, J.; Chen, J.P. A comprehensive review on biosorption of heavy metals by algal biomass: Materials, performances, chemistry, and modeling simulation tools. Bioresour. Technol. 2014, 160, 67-78. [CrossRef] [PubMed]

149. Marques, A.; Rangel, A.; Castro, P. Remediation of heavy metal contaminated soils: Phytoremediation as a potentially promising clean-up technology. Crit. Rev. Environ. Sci. Technol. 2009, 39, 622-654. [CrossRef]

150. Wuana, R.A.; Okieimen, F.E. Heavy metals in contaminated soils: A review of sources, chemistry, risks and best available strategies for remediation. ISRN Ecol. 2011, 2011, 20. [CrossRef]

151. Nowack, B.; Schulin, R.; Robinson, B.H. Critical assessment of chelant-enhanced metal phytoextraction. Environ. Sci. Technol. 2006, 40, 5225-5232. [CrossRef]

152. Fashola, M.O.; Ngole-Jeme, V.M.; Babalola, O.O. Heavy metal pollution from gold mines: Environmental effects and bacterial strategies for resistance. Int. J. Environ. Res. Public Health 2016, 13, 1047. [CrossRef] [PubMed]

153. Azubuike, C.C.; Chikere, C.B.; Okpokwasili, G.C. Bioremediation techniques-classification based on site of application: Principles, advantages, limitations and prospects. World J. Microbiol. Biotechnol. 2016, 32, 180. [CrossRef]

154. Vogt, C.; Richnow, H.H. Bioremediation via in situ microbial degradation of organic pollutants. In Geobiotechnology II. Advances in Biochemical Engineering/Biotechnology; Schippers, A., Glombitza, F., Sand, W., Eds.; Springer: Berlin/Heidelberg, Germany, 2013; Volume 142, pp. 123-146.

155. Roy, A.; Dutta, A.; Pal, S.; Gupta, A.; Sarkar, J.; Chatterjee, A.; Saha, A.; Sarkar, P.; Sar, P.; Kazy, S.K. Biostimulation and bioaugmentation of native microbial community accelerated bioremediation of oil refinery sludge. Bioresour. Technol. 2018, 253, 22-32. [CrossRef]

156. Liu, L.; Li, W.; Song, W.; Guo, M. Remediation techniques for heavy metal-contaminated soils: Principles and applicability. Sci. Total. Environ. 2018, 633, 206-219. [CrossRef]

157. Das, S.; Dash, H.R. 1-microbial bioremediation: A potential tool for restoration of contaminated areas. In Microbial Biodegradation and Bioremediation; Das, S., Ed.; Elsevier: Amsterdam, The Netherlands, 2014; pp. 1-21.

158. Silva-Castro, G.A.; Uad, I.; Rodríguez-Calvo, A.; González-López, J.; Calvo, C. Response of autochthonous microbiota of diesel polluted soils to land-farming treatments. Environ. Res. 2015, 137, 49-58. [CrossRef]

(C) 2019 by the author. Licensee MDPI, Basel, Switzerland. This article is an open access article distributed under the terms and conditions of the Creative Commons Attribution (CC BY) license (http://creativecommons.org/licenses/by/4.0/). 